\title{
Um "tribunal orientado para a vítima": o minimalismo de Nils Christie e as suas contribuições à justiça restaurativa
}

\author{
A "victim-oriented court": Nils Christie's minimalism \\ and its contributions to restorative justice
}

\section{Eduardo Bolsoni Riboli ${ }^{\mathbf{1}}$}

Universidade de Lisboa - Portugal eduardoriboli@gmail.com

http://lattes.cnpq.br/9159008933150913

http://orcid.org/0000-0002-8691-3390

\begin{abstract}
Resumo: Partindo de ideias defendidas por Nils Christie como a noção de que toda pena é uma imposição intencional de dor, do "roubo do conflito" pelo Estado e da necessidade de integração comunitária para a criação e o reforço de valores sociais essenciais para a consolidação de um senso de justiça, o presente estudo tem como principal objetivo analisar pormenorizadamente as contribuições do referido autor à justiça restaurativa hodierna. Mediante uma pesquisa exploratória e descritiva realizada a partir de revisão bibliográfica e documental nacional e internacional, propomo-nos a analisar o problema da possibilidade de elaboração e aplicação de métodos alternativos de solução de conflitos criminais. Verificar-se-á como a vítima pode reconquistar o protagonismo no processo de solução de conflitos, através do que Christie denominou "tribunal orientado para a vítima": um sistema humanitário de solução
\end{abstract}

1 Doutorando em Direito (Ciências Jurídico-Criminais) pela Universidade de Lisboa (Portugal). Mestre em Ciências Jurídico-Criminais pela Universidade de Coimbra (Portugal), em 2017. Especialista em Direito Penal e Política Criminal: Sistema Constitucional e Direitos Humanos pela Universidade Federal do Rio Grande do Sul - UFRGS (Brasil), em 2017. Bacharel em Direito pela Pontifícia Universidade Católica do Rio Grande do Sul - PUCRS (Brasil), em 2013. Membro (bolsista pela FCT) do Ratio Legis - Centro de Investigação e Desenvolvimento em Ciências Jurídicas da Universidade Autónoma de Lisboa (Portugal). 
de conflitos criminais que possibilita à vítima a efetiva realização de justiça. Demonstrar-se-á como as ideias desenvolvidas pelo criminólogo norueguês influenciaram o paradigma atual de justiça restaurativa. Ao final, mediante abordagem crítica, analisar-se-á a compatibilidade da prática restaurativa portuguesa denominada mediação penal "de adultos" com os fundamentos do paradigma restaurativo e os ideais defendidos por Christie.

Palavras-Chave: minimalismo penal; Nils Christie; tribunal orientado para a vítima; justiça restaurativa; mediação penal de adultos.

AвSTRACt: Starting from ideas defended by Nils Christie as the notion that all punishment is an intentional imposition of pain, the fact that the State has stolen the conflict from the victim and the need for community integration for the creation and strengthening of social values essential for the consolidation of a sense of justice, the present study aims to analyze in detail the contributions of the aforementioned author to restorative justice. Through exploratory and descriptive research based on national and international bibliographic and documentary revision, we propose to analyze the problem of the possibility of elaboration and application of alternative methods of solving criminal conflicts. It will be verified how the victim can regain their role in the conflict resolution process, through what Christie has called a "victim-oriented court": a humanitarian system for solving criminal conflicts that enables the victim to effectively carry out justice. We show how the ideas developed by the Norwegian criminologist influenced the current paradigm of restorative justice. At the end, through a critical approach, we will analyze the compatibility of the Portuguese restorative practice called "adult" criminal mediation with the foundations of the restorative paradigm and Christie's ideals.

KEYWORDS: penal minimalism; Nils Christie; victim-oriented court; restorative justice; adult criminal mediation.

SUMÁRIO: Introdução; 1. O abolicionismo penal e as contribuições de Nils Christie; 1.1. O(s) abolicionismo(s) penal(is); 1.2. A teoria minimalista de Nils Christie; 2. A proposta de Nils Christie para a solução de conflitos criminais; 2.1. Premissas; 2.1.1. A necessidade de estreitamento dos laços sociais; 2.1.2. O "roubo do conflito" pelo Estado; 2.2. O "tribunal orientado para a vítima" de Nils Christie como uma nova forma de solução de conflitos; 3. Contributos da teoria minimalista de Nils Christie para as práticas restaurativas penais; 3.1 . Ajustiça restaurativa; 3.2. A influência dos ideais de Nils Christie no atual paradigma restaurativo; 3.3. Notas sobre a mediação penal de adultos em Portugal; Considerações finais; Referências. 


\section{INTRODUÇÃO}

Por desenvolver ideias que possibilitaram repensar o modelo tradicional de justiça penal e elaborar meios alternativos de solução de conflitos criminais - como a necessidade de busca de alternativas à punição e não punições alternativas ${ }^{2}$ e a devolução dos conflitos à vítima através de tribunais comunitários -, Nils Christie é hoje uma das principais referências na literatura dedicada ao estudo da justiça restaurativa ${ }^{3}$.

Partindo inicialmente dos conceitos desenvolvidos por Nils Christie de que a pena é uma imposição intencional de dor, da necessidade de união comunitária para o fortalecimento de valores sociais e do "roubo do conflito" pelo Estado, o presente estudo tem por objetivo expor pormenorizadamente as ideias centrais da teoria minimalista de Christie, de modo a responder

2 "One of the rules would then be: If in doubt, do not pain. Another rule would be: Inflict as little pain as possible. Look for alternatives to punishments, not only alternative punishments. It is often not necessary to react; the offender as well as the surroundings know it was wrong" ("Uma das regras seria: se em dúvida, não infligir dor. Outra regra seria: infligir o mínimo de dor possível. Busque alternativas à punição, não somente punições alternativas. Muitas vezes não é necessário reagir; o ofensor, assim como aqueles que estão ao seu redor, têm ciência do erro") (CHRISTIE, Nils. Limits to Pain: The Role of Punishment in Penal Policy. Eugene: Wipf and Stock Publishers, 2007, p. 11 - tradução e destaques nossos).

3 Inegavelmente assim considerado por investigadores dedicados ao estudo da justiça restaurativa e do abolicionismo penal. A título de exemplo, Howard Zehr, reconhecido pela doutrina como um dos fundadores do modelo contemporâneo de justiça restaurativa, presta agradecimentos específicos à Nils Christie no prefácio de sua célebre obra "Changing lenses: a new focus for crime and justice", reconhecendo que as contribuições deste autor o ajudaram "a apontar um caminho" (ZEHR, Howard. Changing lenses: a new focus for crime and justice. Scottdale: Herald Press, 1990, p. 11). Van Ness e Karen Strong também apontam a relevância do pensamento de Nils Christie para a estruturação do pensamento restaurativo atual (NESS, Daniel W. Van; STRONG, Karen Heetderks. Restoring justice: an introduction to restorative justice. $4^{\text {th }}$ ed. New Providence: LexisNexis, 2010, p. 13). Assim também reconhece Tony Marshall (em MARSHALL, Tony. The evolution of restorative justice in Britain. European Journal on Criminal Policy and Research, The Hague, Amsterdam, New York, v. 4, n. 4, p. 21-43, 1996, p. 36). Destaque também apontado, entre inúmeros outros teóricos, por CARRIER, Nicolas; PICHÉ, Justin. The State of Abolitionism. Champ Pénal/Penal Field, Paris, v. XXI, 2015; e SANTOS, Cláudia Cruz. A justiça restaurativa: um modelo de reacção ao crime diferente da justiça penal: porquê, para quê e como?. Coimbra: Coimbra Editora, 2014, pp. 61-72. 
aquele que é um dos questionamentos mais inquietantes em tema de direito penal e processo penal hodiernamente: diante do fracasso do atual sistema de justiça penal e da pena de prisão, é possível elaborar (e aplicar) métodos alternativos de solução de conflitos criminais? Em segundo lugar, analisaremos se é possível cogitar um modelo em que a vítima assuma o protagonismo do processo de solução de seu conflito e verificaremos como ela, em um encontro junto ao ofensor e a outros membros da comunidade, pode encontrar a solução que julga mais adequada ao seu caso.

Trata-se de uma pesquisa exploratória e descritiva, efetuada a partir de revisão bibliográfica e documental nacional e internacional, reservada a abordar conceitos fundamentais do abolicionismo penal para a correta compreensão da dimensão do problema e avançar nos conceitos centrais do minimalismo de Nils Christie para o enfrentamento e solução da problemática proposta.

Este estudo tem como objetivo expor as ideias centrais da teoria abolicionista (minimalista) desenvolvida por Nils Christie e demonstrar como a sua teoria contribuiu para estruturar a justiça restaurativa. Ao final, é realizada análise crítica acerca da influência dos ideais de Christie na prática restaurativa no ordenamento jurídico português denominada mediação penal "de adultos".

\section{O abolicionismo penal e as contribuições de Nils Christie}

\subsection{O(s) ABOLICIONISMO(S) PENAL(IS)}

Foi com forte influência das observações apontadas pelas teorias sociológicas do crime e pela criminologia crítica da década de 60 do século $\mathrm{XX}$ - sobretudo a inquietude quanto à origem do crime, o curioso fenômeno da deviance e as mazelas provocadas pelas instâncias (in)formais de controle e pelo sistema penal lato sensu $u^{4}$ - que as teorias criminológicas abolicionistas se desenvolveram. ${ }^{5}$

4 ANDRADE, Manuel da Costa; DIAS, Jorge de Figueiredo. Criminologia: O Homem Delinquente e a Sociedade Criminógena. Coimbra: Coimbra Editora, 2013, p. 41 e ss.

5 Cf. BAILONE, Matías. En busca de una sensata cantidad de abolicionismo: de la conciencia política al desarrollo académico. In: POSTAY, Maximiliano E. 
Assim como as correntes da criminologia crítica, as teorias abolicionistas também se apresentam de maneira pluriforme e variam de acordo com a realidade social e jurídica do local onde foram desenvolvidas. Para determinados autores, a pluralidade de teorias abolicionistas e a multiplicidade de críticas e contribuições delas oriundas acabam por tornar o termo abolicionismo polissêmico ${ }^{6}$, pois o abolicionismo nem sempre é voltado unicamente ao campo penal ${ }^{7}$. Bianchi expõe com agudeza esta amplitude de significados ao optar por definir o abolicionismo como um sintoma da tendência natural humana em eliminar e lutar contra os fenômenos ou instituições de natureza social, política ou religiosa que, em uma determinada época, são considerados injustos ou equivocados. ${ }^{8}$ Verificamos no abolicionismo esta mesma abrangência e concordamos com Vincenzo Ruggiero quando pontua que o abolicionismo não é somente uma estratégia ou então um conjunto de ideias ou reivindicações que têm como objetivo a redução ou supressão da prisão, é também uma perspectiva, uma abordagem, uma ideia, uma filosofia. ${ }^{9}$ Abolicionismo

(comp.). El abolicionismo penal en América Latina: imaginación no punitiva y militancia. Buenos Aires: Editores del Puerto, 2012, p. 104; COHEN, Stan. Introducción. In: CIAFARDINI, Mariano Alberto; BONDANZA, Mirta Lilián (orgs.). Abolicionismo Penal. Buenos Aires: Ediar Sociedad Anonima Editora, Comercial, Industrial y Financiera, 1989, p. 13; ZAFFARONI, Eugenio Raúl. Em busca das penas perdidas: a perda da legitimidade do sistema penal. Tradução: Vania Romano Pedrosa, Amir Lopes da Conceição. Rio de Janeiro: Revan, 1991, pp. 60, 88-89, 97; LARRAURI, Elena. La herencia de la criminología crítica. $2^{\mathrm{a}}$ ed. México: Siglo XXI Editores, 1992, p. 197 e ss.; ANDRADE, Manuel da Costa; DIAS, Jorge de Figueiredo. Op. cit., p. 243 e ss; PALLAMOLLA, Raffaella da Porciuncula. Justiça restaurativa: da teoria à prática. São Paulo: IBCCRIM, 2009, pp. 37-41.

6 CARRIER, Nicolas; PICHÉ, Justin. Op. cit.

7 Como explicam Nicolas Carrier e Justin Piché, o(s) abolicionismo(s) nem sempre é(são) limitado(s) ao campo penal, e quando o é(são) há uma distinção de suas vertentes no que toca às críticas entre a prisão, pena e cárcere, o que por vezes inclusive pode acarretar em uma ideia errônea de que uma teoria sucede a outra, quando na verdade elas em sua maior parte são concomitantes (cf. CARRIER, Nicolas; PICHÉ, Justin. Op. cit.).

8 BIANCHI, Herman Thomas. Abolitionism in the Past, Present and Future. In: LASOCIK, Zbigniew; PLATEK, Monika; RZEPLIÂNSKA, Irena (Ed.). Abolitionism in History: On Another Way of Thinking. Warszawa: Instytut Profilaktyki Spolecznej i Resocjalizacji Uniwersytetu Warszawskiego, 1991, p. 29.

9 RUGGIERO, Vicenzo. The Legacy of Abolitionism. Champ Pénal/Penal Field, Paris, v. XXI, 2015; RUGGIERO, Vincenzo. An abolitionist view of restorative 
é, ao final, uma postura, é o ato de dizer "não!" ao sofrimento e às instituições injustas ou cruéis, como defende Mathiesen ${ }^{10}$. Ater-nos-emos, no presente estudo, às contribuições derivadas do desenvolvimento das múltiplas teorias abolicionistas críticas do sistema penal lato sensu ${ }^{11}$.

Mesmo não havendo um verdadeiro consenso doutrinário quanto à classificação das teorias abolicionistas, admite-se a sua divisão em duas grandes vertentes: (a) o abolicionismo (ou abolicionismo radical), que visa a completa extinção do sistema penal e a sua substituição por outro sistema que seja efetivamente justo e não cause sofrimento; e (b) o minimalismo, em suas diferentes ramificações ${ }^{12}$, que em sentindo amplo visa limitar ao máximo a atuação do sistema penal tradicional e a violência por ele causada, sugerindo novos meios de solução de conflitos, porém ao mesmo tempo reconhecendo a necessidade de manutenção

justice. International Journal of Law, Crime and Justice, Amsterdam, v. 39, n. 2, p. 100-110, 2011, pp. 100-101.

10 MATHIESEN, Thomas. The Abolitionist Stance. Journal of Prisoners on Prisons, Ottawa, v. 17, n. 2, p. 58-63, 2008, p. 58.

11 Com especial dedicação à teoria abolicionista minimalista de Nils Christie.

12 De acordo com Vera Regina Pereira de Andrade, o minimalismo pode ser classificado em três vertentes: (a) o minimalismo como meio para o abolicionismo radical; (b) o minimalismo como fim em si mesmo; e (c) o minimalismo como reforma penal. O primeiro diz respeito aos modelos que apostam no minimalismo a curto e médio prazo como um meio para concretizar o ideal abolicionista, partindo-se do pressuposto de aceitação da deslegitimação do sistema penal e de sua crise estrutural, as quais não poderiam ser revertidas no presente nem no futuro. Seus principais defensores são Alessandro Baratta e Eugenio Raúl Zaffaroni. O segundo, que tem como um de seus expoentes defensores Luigi Ferrajoli, também parte da aceitação da deslegitimação do sistema penal, porém aposta na sua relegitimação sob o viés do direito penal mínimo, este pautado na racionalidade jurídico-penal, na limitação do poder punitivo e na efetiva tutela do indivíduo contra arbitrariedades. Por fim, a última vertente é caracterizada pela reunião de reformas penais, processuais penais e penitenciárias que visam reestruturar o sistema penal através de princípios como a intervenção mínima, prisão como ultima ratio e penas alternativas (ANDRADE, Vera Regina Pereira de. Pelas mãos da criminologia: o controle penal para além da (des)ilusão. Rio de Janeiro: Revan, 2012, p. 257 e ss.; ver também ÁVILA, Gustavo Noronha de. O debate entre Luigi Ferrajoli e os abolicionistas: entre a sedução pelo discurso do medo e as práticas libertárias. Revista Jurídica Cesumar, São Paulo, v. 16, n. 2, p. 543-561, 2016, p. 546 e ss.; ACHUTTI, Daniel Silva. Justiça Restaurativa e Abolicionismo Penal. São Paulo: Saraiva, 2014, pp. 91 e ss.). 
do sistema tradicional de justiça criminal ou de sistemas semelhantes para casos excepcionais. ${ }^{13}$

Não há contradição entre as diferentes teorias abolicionistas, apenas distinção no grau de intensidade do encolhimento do direito penal e nas soluções alternativas propostas. Enquanto algumas teorias pugnam pela extinção completa do sistema penal ${ }^{14}$, outras o admitem em casos excepcionais $^{15}$ - casos em que o direito penal somente encontraria legitimidade após a tentativa frustrada de solução do conflito por outros meios não-penais e desde que demonstrado ser o sistema penal extremamente necessário.

Independentemente da corrente adotada, todas as teorias abolicionistas têm como denominador comum a crítica ao modo como o Estado resolve os conflitos criminais - os quais, em uma acepção abolicionista, passam a ser identificados como conflitos sociais, ou então "situações problemáticas” ${ }^{16}$, como definido por Hulsman — através do sistema pe-

13 SCHEERER, Sebastian. Hacia el Abolicionismo. In: CIAFARDINI, Mariano Alberto; BONDANZA, Mirta Lilián (orgs.). Abolicionismo Penal. Buenos Aires: Ediar Sociedad Anonima Editora, Comercial, Industrial y Financiera, 1989, pp. 15-34; ANDRADE, Vera Regina Pereira de. Op. cit., pp. 253-273; ACHUTTI, Daniel Silva. Justiça Restaurativa e... cit., pp. 91-96; FERREIRA, Francisco Amado. Justiça Restaurativa: Natureza, Finalidades e Instrumentos. Coimbra: Coimbra Editora, 2006, pp. 13-24; CARRIER, Nicolas; PICHÉ, Justin. Op. cit.; TIEGHI, Osvaldo Nelo. El abolicionismo radical y el abolicionismo institucional. Revista Chilena de Derecho, Santiago, v. 22, n. 2, p. 309-319, 1995, passim.

14 Entre elas as teorias abolicionistas radicais de Louk Hulsman (cf., sobretudo, HULSMAN, Louk; CELIS, Jacqueline Bernat de. Penas Perdidas: O Sistema Penal em Questão. Tradução: Maria Lúcia Karam. $2^{\mathrm{a}}$ ed. Niterói: Luam, 1997) e Thomas Mathiesen (cf., principalmente, a edição atualizada de sua célebre obra "The Politics of Abolition": MATHIESEN, Thomas. The Politics of Abolition Revisited. Abingdon: Routledge, 2015; e também MATHIESEN, Thomas. Prison on Trial. 3rd ed. Winchester: Waterside Press, 2006).

15 Como o minimalismo de Nils Christie, o qual compõe um dos objetos do presente estudo.

16 Termo cunhado por Hulsman (HULSMAN, Louk H. C. Critical criminology and the concept of crime. Contemporary Crises, Amsterdam. v. 10, p. 63-80, 1986, p. 72). Hulsman também adota o termo "situação-problema" posteriormente (cf. HULSMAN, Louk; CELIS, Jacqueline Bernat de. Op. cit., p. 95 e ss.). Sobre a importância do vocabulário a ser utilizado, observa Hulsman: "A eliminação do conceito de 'crime' obriga uma completa renovação de todo o 
nal; assim como a crítica à pena, ao funcionamento do sistema penal, aos estigmas que ele cria e propaga, e às soluções que ele promete conferir (mas que não cumpre). ${ }^{17}$

O abolicionismo critica as definições tradicionais de crime, de lei e as visões do sentido e efeito da punição e do encarceramento. $\mathrm{Na}$ perspectiva abolicionista, a pena de prisão é ineficaz e não impede a prática de crimes, serve apenas para agravar o sofrimento humano, acepção que estrutura as propostas de formas alternativas (não-penais) de solução para situações problemáticas, como as práticas restaurativas ${ }^{18}$.

Em síntese, o abolicionismo visa "encolher o sistema penal"19 - conforme afirmava Nils Christie - mediante o questionamento da legitimidade da pena de prisão e do tradicional sistema de justiça penal e a aposta em meios alternativos mais humanitários para solução dos problemas tradicionalmente submetidos ao sistema penal.

discurso em torno do chamado fenômeno criminal e da reação social que ele suscita. Em primeiro lugar, é preciso mudar a linguagem. (...) Seria preciso se habituar a uma linguagem nova, capaz de exprimir uma visão não estigmatizante sobre as pessoas e situações vividas" (HULSMAN, Louk; CELIS, Jacqueline Bernat de. Op. cit., pp. 95-96). Sobre este e outros temas, ver também HULSMAN, Louk. El enfoque abolicionista: politicas criminales alternativas. In: RODENAS, Alejandra; FONT, Enrique Andrés; SAGARDUY, Ramiro A. P. (dirs.). Criminologia Critica y Control Social: 1. "El Poder Punitivo del Estado". Rosario: Juris, 1993, p. 175-104; e SANTOS, Cláudia Cruz. A justiça restaurativa... cit., p. 307 e ss.).

17 Para uma síntese muito apurada sobre o tema, cf. MATHIESEN, Thomas. The Abolitionist Stance. Journal of Prisoners on Prisons, Ottawa, v. 17, n. 2, p. 5863, 2008.

Como a mediação, a composição civil, grupos de conversa, os círculos e outras práticas restaurativas (ALVESALO-KUUSI, Anne; BITTLE, Steven; LÄHTEENMÄKI, Liisa. Corporate Criminal Liability and Abolitionism - An unholy alliance of corporate power and critical criminology?. Justice, Power and Resistance, London, v. 1, n. 1, p. 24-46, 2017, pp. 24-25. Ver também PAVARINI, Massimo. Strategy for combat: prisoners' rights and abolitionism. Justice, Power and Resistance, London, v. 1, n. 1, p. 67-79, 2017, p. 74 e ss; e DEVOTO, Eleonora; JULIANO, Mario Alberto. Un sistema penal alternativo. Hacia la abolición de la violencia institucional. In: POSTAY, Maximiliano E. (comp.). El abolicionismo penal en América Latina: imaginación no punitiva y militancia. Buenos Aires: Del Puerto, 2012, pp. 109-116).

19 OLIVEIRA, Ana Sofia Schmidt de; FONSECA, André Isola. Conversa com um abolicionista minimalista. Revista Brasileira de Ciências Criminais, São Paulo, A. 6, n. 21, p. 13-22, 1998, p. 14. 


\subsection{A teoria minimalista de Nils Christie}

Ao longo de seu percurso acadêmico, Nils Christie defendeu uma posição minimalista de abolicionismo penal, em que a intervenção penal estatal deveria ser restringida ao máximo, somente operável em casos excepcionais, de modo a evitar os males provocados pela "cara e destrutiva" ${ }^{20}$ prisão. ${ }^{21}$

As críticas e teorias formuladas pelo autor são dotadas de peculiaridade por partirem da premissa de que a imposição de uma sanção significa a "imposição intencional de dor" 22 - principalmente no que diz respeito à condenação à pena de prisão —, ideia medular que fundamenta todo o seu desenvolvimento teórico.

A sanção serviria, portanto, somente para causar dor e sofrimento ao condenado, não para curá-lo ${ }^{23}$. O patente sofrimento outrora infligido pela cominação de penas de castigos corporais ou pena de morte tornou-se invisível para grande parte da sociedade com o surgimento e adoção da pena de prisão em diferentes sistemas de justiça penal. A dor que antes era perceptível já não é mais explícita. Por ter se esquecido desta imposição de dor, ou por ela ter sido ofuscada, a sociedade apenas lembra de sua existência quando instigada à reflexão acerca das finalidades e dos resultados da pena de prisão ${ }^{24}$.

Hodiernamente, a punição - sobretudo a pena de prisão - é encarada como uma consequência automática do crime. A relação é

20 Como classifica Nils Christie, em entrevista (OLIVEIRA, Ana Sofia Schmidt de; FONSECA, André Isola. Op. cit., p. 13).

21 OLIVEIRA, Ana Sofia Schmidt de; FONSECA, André Isola. Op. cit., pp. 13-14 e 16; CHRISTIE, Nils. Uma razoável quantidade de crime. Tradução, apresentação e notas: André Nascimento. $1^{\mathrm{a}}$ reimpr. Rio de Janeiro: Editora Revan, 2013, pp. 130-131.

22 CHRISTIE, Nils. Limits to Pain... cit., pp. 5-6. "Punishment is an evil intended to be so. It has to do with suffering. (...) Someone is to suffer a pain that is intended" (CHRISTIE, Nils. Images of man in modern penal law. Contemporary Crises, Dordrecht, v. 10, n. 1, p. 95-106, 1986, p. 95). Ver também CHRISTIE, Nils. Victim Movements at a crossroad. Punishment \& Society, London, v. 12, n. 2, p. $115-122,2010$, p. 118 e ss.

CHRISTIE, Nils. Limits to Pain... cit., pp. 13-19. 
considerada lógica: a prática de uma conduta criminosa pressupõe a imposição de uma pena privativa de liberdade ao seu autor. A imposição da dor é automaticamente aceita pela sociedade, sem questionamentos. Parece haver mais preocupação com a intensidade da dor imposta do que com a sua necessidade ou então com a possibilidade de emprego de mecanismos alternativos capazes de controlar o comportamento classificado como desviante. ${ }^{25}$

Diante de tais constatações, indaga Nils Christie: seria mesmo necessária a imposição de dor para o controle de certos comportamentos? Poderíamos conceber, aceitar e colocar em prática um sistema sem punição, sem sofrimento? O autor defende que a ausência de punições daria origem ao caos, pois na ausência de medidas capazes de coibir comportamentos contrários ao ordenamento jurídico as taxas de criminalidade certamente aumentariam ${ }^{26}$. Destarte, reconhece a necessidade de solução de situações problemáticas, porém defende que para quase a totalidade dos conflitos - principalmente aqueles menos perniciosos - seria de fato possível operar um sistema sem sofrimento, através da adoção de medidas mais humanitárias. Estes meios alternativos de solução de conflitos não seriam operados através da imposição de uma dor, o que significaria a ausência (ou ao menos a significativa mitigação) de sofrimento tanto para o indivíduo que pratica a conduta contrária ao Direito quanto para os demais envolvidos, principalmente a própria vítima, evitando-se possíveis casos de vitimização secundária.

Entretanto, o autor reconhece a necessidade de manutenção de uma certa quantia de dor em casos excepcionais (situações de elevadíssima gravidade ou para indivíduos “de alta periculosidade”), uma dor que seria ministrada através da imposição de uma pena privativa de liberdade ou de uma intervenção terapêutica. Estas medidas seriam aplicadas subsidiariamente, somente após a constatação da inexistência de vias mais humanitárias aptas a solucionar o conflito ou inibir a prática do ato lesivo. Sempre que possível, o tratamento do indivíduo (intervenção terapêutica) deveria ser priorizado. Mesmo que a intervenção terapêutica também implique a imposição de uma dor, esta dor deveria

25 CHRISTIE, Nils. Limits to Pain... cit., pp. 32-48.

26

CHRISTIE, Nils. Limits to Pain... cit., pp. 31-32. 
ser encarada como eticamente aceitável por não possuir aquela finalidade única de provocar sofrimento, devendo ser compreendida como uma cura dolorosa. Não sendo o tratamento possível, adequado ou aceitável, a pena privativa de liberdade surge como (última) alternativa, destinada a indivíduos diagnosticados como perigosos. Neste segundo caso restaria evidente a imposição de dor e sofrimento, os quais deveriam ser encarados como inevitáveis para impedir a dor e o sofrimento de outros indivíduos, particularmente das vítimas em potencial. ${ }^{27}$

O autor reconhece, portanto, a finalidade de prevenção geral que a pena representa, porém repudia um sistema penal unicamente focado a este fim. Isso porque, nesta acepção, a punição teria como objetivo a simples conformidade ao ordenamento jurídico: o criminoso não seria punido apenas em razão de sua conduta, mas também para o controle de outras pessoas, servindo como mero exemplo pedagógico ${ }^{28}$.

Christie - assim Louk Hulsman ${ }^{29}$ - negava a natureza ontológica do crime. O criminólogo norueguês defendia a ideia de que "o crime não

27 CHRISTIE, Nils. Limits to Pain... cit., pp. 20-22.

28 Como ocorre com as perspectivas utilitaristas da finalidade da pena (GIAMBERARDINO, André Ribeiro. O confisco do conflito na histografia penal. Revista Eletrônica Direito e Sociedade, Canoas, v. 6, n. 2, p. 23-39, 2018, pp. 24-25; GIAMBERARDINO, André Ribeiro. A construção social da censura e a penologia um passo além: reparação criativa e restauração. Sistema Penal \& Violência, Porto Alegre, v. 6, n. 1, p. 88-102, 2014, p. 94 e ss.; RUIVO, Marcelo Almeida. O fundamento da pena criminal: para além da classificação dicotômica das finalidades. Revista Portuguesa de Ciência Criminal, Coimbra, A. 22, n. 2, p. 175-199, 2012, p. 185 e ss.; BURGH, Richard W. Do the Guilty Deserve Punishment?. The Journal of Philosophy, [S. 1.], v. 79, n. 4, p. 193-210, 1982, pp. 194-195). Howard Zehr também afasta esta perspectiva utilitarista e meramente retributiva ao afirmar que o objetivo da punição e da reparação deve ser a transmissão de uma mensagem, porém não mais a mensagem utilitarista de que crimes não devem ser cometidos por violarem a lei e que criminosos devem ser punidos por terem cometido um ilícito penal. Para Zehr, a mensagem deve ser pautada em uma perspectiva reparadora que transmita a ideia de que o ilícito penal não deve ser cometido porque prejudica uma outra pessoa e que aqueles que provocam um dano a outro devem reparar este mesmo dano (ZEHR, Howard. Changing lenses... cit., pp. 198-199).

29 Sobre a negação da natureza ontológica do crime sob a perspectiva de Hulsman, cf. HULSMAN, Louk H. C. Critical criminology and... cit., pp. 63-66 e ss.; e HULSMAN, Louk; CELIS, Jacqueline Bernat de. Op. cit., p. 95 e ss. 
existe" ${ }^{30}$, o que existiria, na verdade, seriam atos que ganhariam significado(s) a partir da interpretação de terceiros interessados no exercício do controle ${ }^{31}$. Destarte, para Christe o crime seria uma construção social, um conceito aplicável a determinadas situações sociais indesejadas por um restrito grupo de pessoas dotadas de influência ou legitimidade para criminalizar tais condutas ${ }^{32}$, por motivos particulares ou em razão de valores reconhecidos por uma certa camada da sociedade ${ }^{33}$.

É com base nestas suas premissas que Christie defendia ser necessário conferir um olhar diferente para o conceito de crime. Defendia que o crime não é um conceito fechado, imutável e permanente, e afirmava que a própria sociedade contribui para o surgimento e para a perpetuação

30 CHRISTIE, Nils. A indústria do Controle do Crime: a caminho dos GULAGs em estilo ocidental. Tradução: Luís Leiria. Rio de Janeiro: Forense, 1998, p. 13; CHRISTIE, Nils. Uma razoável quantidade... cit., pp. 16-31; CHRISTIE, Nils. Victim Movements at... cit., pp. 118-119. Observa Nils Christie: "Uma má ação pode ser analisada sob diversos enfoques: se for analisada sob o enfoque penal, uma má ação será transformada em crime; se for analisada sob o enfoque médico será transformada em doença; se por nós, diremos que na sociedade moderna, analisada no contexto da vida cotidiana, será vista como um problema” (OLIVEIRA, Ana Sofia Schmidt de; FONSECA, André Isola. Op. cit., pp. 13-14).

31 "Atos não são, eles se tornam alguma coisa. O mesmo acontece com o crime. O crime não existe. É criado. Primeiro, existem atos. Segue-se depois um longo processo de atribuir significado a esses atos" (CHRISTIE, Nils. A indústria do... cit., p. 13). "O sistema penal é análogo ao rei Midas. Tudo o que este tocava se tornava ouro e, como sabemos, ele morreu de fome. Muito do que a polícia e a prisão tocam se converte em crimes e criminosos, e interpretações alternativas de atos e atores se desvanecem. (...) Uma ampla rede também aumentará as chances de que se encontrem pessoas definidas pelas autoridades como criminosas. Voltamos, assim, ao meu tema geral: atos não são; eles se tornam. Pessoas não são; elas se tornam. Uma larga rede social com ligações em todas as direções cria incerteza, no mínimo, sobre o que é crime e quem são os criminosos" (CHRISTIE, Nils. Uma razoável quantidade... cit., p. 23). Ver também CHRISTIE, Nils. Limits to Pain... cit., pp. 73-74 e ss. Perspectiva semelhante é abordada em ZEHR, Howard. Changing lenses... cit., capítulo 10, especialmente pp. 181 e ss. CHRISTIE, Nils. Limits to Pain... cit., p. 74.

33 Questão acuradamente analisada por Howard Becker, principalmente quando estuda os grupos de indivíduos que classifica como "empreendedores morais” (cf. BECKER, Howard Saul. Outsiders: estudos de sociologia do desvio. Tradução: Maria Luiza X. de A. Borges. Rio de Janeiro: Jorge Zahar Editora, 2008, p. 22 e ss.; p. 153 e ss.). 
do crime, em razão dos próprios sistemas que criamos, sistemas estes que clamam pela palavra crime ${ }^{34}$. Acreditava que o crime poderia ser extinto, ou ao menos reduzido significativamente, caso fossem criados outros meios capazes de solucionar os conflitos existentes na sociedade, meios diferentes e mais eficazes que aqueles apresentados pelo sistema penal tradicional ${ }^{35}$. Deveríamos, portanto, encarar o crime - ou, nas palavras de Christie, o conflito ou o problema - de uma forma completamente diferente e solucioná-lo por outras vias.

\section{A proposta de Nils Christie para a solução de CONFLITOS CRIMINAIS}

\subsection{PREMISSAS}

\subsubsection{A NECESSIDADE DE ESTREITAMENTO DOS LAÇOS SOCIAIS}

Como premissa à proposta de um método alternativo para a solução de conflitos, o autor afasta a necessidade de busca por uma justificativa à punição e adota uma perspectiva sem tal preocupação, a qual possibilitaria que o ser humano pudesse ser visto como uma pessoa complexa que interage com outras pessoas complexas, criando as suas próprias regras e também criando justiça de acordo com cada caso apresentado ${ }^{36}$.

34 Christie pontua com precisão a importância que os paradigmas têm em moldar nossas expectativas: "Um guerreiro veste armadura, um amante traz consigo flores. Eles estão equipados de acordo com as expectativas do que acontecerá, e os seus equipamentos aumentam a possibilidade de realização destas expectativas. O mesmo ocorre com o direito penal" (Tradução nossa. No original: "A warrior wears armour, a lover flowers. They are equipped according to expectations of what is to happen, and their equipment increases chances that their expectations will prove right") (CHRISTIE, Nils. Images of man... cit., p. 95).

"Crime is not a 'thing'. Crime is a concept applicable in certain social situations where it is possible and in the interests of one or several parties to apply it. We can create crime by creating systems that ask for the word. We can extinguish crime by creating the opposite types of systems" (CHRISTIE, Nils. Limits to Pain... cit., p. 74).

36 CHRISTIE, Nils. Conflicts as property. The British Journal of Criminology, London, v. 17, n. 1, p. 1-15, 1977, p. 7. Sobre o tema, ver também ACHUTTI, Daniel Silva. Justiça Restaurativa e... cit., p. 111. 
Este é outro ponto-chave que permeia todos os estudos de Christie: o autor acreditava que a busca de alternativas para solução de conflitos deveria ter como ponto de partida a interação entre as pessoas, bem como um senso de união entre os indivíduos localizados em um determinado contexto social ${ }^{37}$ (uma pequena comunidade, um bairro ou um vilarejo, por exemplo). O estreitamento dos laços sociais permitiria a criação e o fortalecimento de valores locais, valores estes essenciais para que os conflitos fossem enfrentados sob a perspectiva daquelas pessoas que vivem na área onde ele ocorreu, o que viabilizaria uma solução mais adequada ao problema, pois seria pautada de acordo com os valores e experiências daquela própria comunidade ${ }^{38}$.

Inexiste, defende o autor, uma verdadeira interação entre as pessoas na sociedade atual. Pelo contrário, o distanciamento tomou o lugar da interação entre os indivíduos. Atualmente conhecemos cada vez menos as pessoas que nos cercam, limitamo-nos a interagir com as pessoas unicamente em razão do papel que elas desempenham em certo contexto social, como se fôssemos "migrantes movendo-se entre conjuntos de pessoas que não necessariamente têm qualquer ligação"39. A divisão da sociedade em "castas" (não somente enquanto classes sociais, mas também por outros atributos como sexo, etnia, limitações físicas e idade, por exemplo), também contribuiria para este afastamento social, na perspectiva de Christie $^{40}$. Inexiste uma efetiva interação entre as pessoas.

Esses seriam fatores que promovem a despersonalização da vida social. O distanciamento e a falta de união acabam impossibilitando que efetivamente conheçamos os nossos pares, como pessoas e não atores que cumprem um papel. $^{41}$

Outra consequência que a segmentação da sociedade apresenta é a de que certos fatos que poderiam ser encarados como problemáticos

37 CHRISTIE, Nils. Conflicts as property... cit., p. 1 et passim.

38 CHRISTIE, Nils. Conflicts as property... cit, pp. 5-10.

39 Tradução nossa. No original: "migrants moving between sets of people which do not need to have any link" (CHRISTIE, Nils. Conflicts as property... cit., p. 5).

40 CHRISTIE, Nils. Conflicts as property... cit., p. 5.

41 CHRISTIE, Nils. Conflicts as property... cit., p. 6. 
deixam de o ser, a exemplo dos crimes contra a honra, justamente porque as pessoas não interagem entre si, o que evidencia a falta de preocupação com a sua imagem perante o corpo social. Nesse sentido, um terceiro e mais grave resultado que o distanciamento social pode provocar é a tendência a tornar invisíveis os conflitos sérios, impossibilitando que haja uma correta solução para o problema, a exemplo da violência doméstica ou de crimes contra as relações de consumo ${ }^{42}$.

Esse distanciamento social dificulta a criação de valores comunitários e, consequentemente, molda a maneira como a sociedade encara o conflito (criminal), distanciando-se do agente, da vítima e dos órgãos de justiça. Christie ressalta, assim, a importância do sentimento de pertença e integração comunitária, a interação em detrimento do isolamento social, para que as pessoas se conheçam, para que seja possível prestar auxílio quando perceberem o surgimento de um problema ${ }^{43}$, fazer justiça e evitar a automática "tentação de buscar ajuda no Direito Penal" ${ }^{4}$.

\subsubsection{O "ROUBO do CONFLITO" PELO Estado}

Além da ideia de união entre indivíduos de uma determinada localidade, ao sugerir novos meios de solução de conflitos Christie destaca que estes não precisam necessariamente ser resolvidos ${ }^{45}$. Os

42 CHRISTIE, Nils. Conflicts as property... cit., pp. 6-7.

43 CHRISTIE, Nils. Limits to pain... cit., pp. 108-116.

44 Nils Christie, em entrevista ao IBCCrim (cf. OLIVEIRA, Ana Sofia Schmidt de; FONSECA, André Isola. Op. cit., p. 21).

45 "First, it is important not to presuppose that conflict ought to be solved. The quest for solution is a puritan, ethnocentric conception. (...) Conflicts might be solved, but they might also be lived with. 'Conflict-handling' is probably a better term. 'Conflict participation' might be the best. That term does not direct attention to the outcome, but to the act. Maybe participation is more important than solutions. Conflicts are not necessarily a 'bad thing'. They can also be seen as something of value, a commodity not to be wasted. Conflicts are not in abundance in a modern society; they are a scarcity. They are in danger of being lost, or often stolen. The victim in a criminal case is a sort of double loser in our society. First vis-à-vis the offender, secondly vis-à-vis the state. He is excluded from any participation in his own conflict" (CHRISTIE, Nils. Limits to pain... cit., pp. 92-93 - destaques nossos). 
conflitos precisam, na verdade, ser manuseados; precisam ser vividos, experienciados. Conflitos podem causar prejuízos, mas também podem servir de aprendizado para as pessoas envolvidas na busca de sua solução, como se fossem uma espécie de ritual de aprendizagem, denominado por Christie de "participação no conflito" ${ }^{46}$. Essa possibilidade de participação no conflito é extremamente valiosa para todos os membros da comunidade em que o conflito surgiu, principalmente para a vítima, pelo potencial de aprendizagem que a busca para a solução do problema revela ${ }^{47}$. É neste sentido que a experiência de lidar com os mecanismos de solução de conflitos se torna mais importante do que a própria solução do problema.

É a partir desta linha interpretativa que Nils Christie delineou uma de suas mais célebres contribuições para a Criminologia, para o Direito Penal e para o Processo Penal, em seu consagrado artigo intitulado Conflicts as property ${ }^{48}$ : a ideia de "roubo do conflito" pelo Estado. O grande problema do sistema de justiça penal atual residiria no fato de ter o Estado retirado (roubado) a possibilidade de a vítima, a comunidade e o próprio ofensor resolverem o seu conflito, de participarem no seu conflito.

Hodiernamente, é o Estado quem representa a vítima e efetua o diálogo com o ofensor, quando na verdade a própria vítima poderia estar interessada no contato com o agente criminoso, por distintas razões (como conhecer o agente para compreender a sua história e as motivações que o levaram a praticar a conduta antijurídica $)^{49}$. O ofensor também perde oportunidades de esclarecimento à vítima. Ademais, a própria

46 CHRISTIE, Nils. Limits to pain... cit., p. 93.

47 A ideia de que os conflitos são valiosos para a sociedade permeia todos os trabalhos de Nils Christie, mas foi abordada primeiramente em Conflicts as property e desenvolvida sob a perspectiva da dor e sofrimento da pena de prisão em Limits to Pain.

CHRISTIE, Nils. Conflicts as property. The British Journal of Criminology, London, v. 17, n. 1, p. 1-15, 1977.

49 “Temos relatos de pessoas que, relatando suas experiências de mediação, disseram: 'No lugar do monstro desconhecido eu vi uma pessoa. Eu tive a chance de mostrar a minha raiva e a minha dor e tive a chance de ouvir as suas razões e suas desculpas'. Com um sistema que possibilite este tipo de contato, você cria um espaço mais amplo de entendimento" (Nils Christie, em entrevista. OLIVEIRA, Ana Sofia Schmidt de; FONSECA, André Isola. Op. cit., p. 14). 
comunidade perde com o roubo do conflito, pois seria a participação na solução do problema que viabilizaria o diálogo sobre a ilicitude do fato, a intensidade do erro do ofensor e as inquietações da vítima, abordando todas as peculiaridades do caso. ${ }^{50}$

Todos, portanto, perdem com o roubo do conflito pelo Estado. Contudo, para Christie a apropriação estatal do conflito é especialmente lesiva à sociedade, pois significa a perda da oportunidade de esclarecimento de normas, regras e valores; uma perda de possibilidades pedagógicas extraídas do processo de solução do conflito.

Desse modo, o foco do Direito Penal - e também de mecanismos alternativos de solução de conflitos - deveria ser a vítima e, subsidiariamente, a sociedade, e não somente o autor do fato criminoso ${ }^{51}$. Nils Christie observa que é preciso desenvolver "um senso crítico em relação ao sistema penal para que [ele] não se torne opressivo. (...) Um sistema penal muito abrangente impede que as pessoas tomem parte nos seus conflitos, nas suas vidas" 52 . Não basta que a vítima seja representada por um profissional ou um advogado, é preciso que a própria vítima faça parte deste processo de solução do conflito, junto a outras pessoas da mesma comunidade em que ela está inserida, para que a partir dos valores de todos os envolvidos seja possível edificar uma solução justa e adequada ao problema. A solução do conflito deveria, portanto, ser encontrada pelos atores diretamente nele envolvidos ${ }^{53}$.

50 CHRISTIE, Nils. Conflicts as property... cit., pp. 7-8. FONSECA, André Isola. Op. cit., p. 14.

SANTOS, Cláudia. Um crime, dois conflitos (e a questão, revisitada, do 'roubo do conflito' pelo Estado). Revista Portuguesa de Ciência Criminal, Coimbra, A. 17 , n. 3, p. 459-474, 2007, p. 459. Nils Christie sintetiza esta ideia e a sua importância: "Os conflitos sociais são transformados pelos operadores do direito em casos. As chamadas vítimas perdem seus próprios casos para seus advogados. (...) Mas não será que eu e você, se formos as partes interessadas, deveríamos conversar? Eu perguntaria: 'Por que você tirou isso de mim?' E você responderia: 'Eu tirei porque eu precisava muito ou porque você tirou outra coisa de mim alguns anos atrás'. A questão é: você prefere ser um sujeito ou um objeto? Você prefere tomar parte de seu conflito ou deixar alguém tomar parte por você?" (OLIVEIRA, Ana Sofia Schmidt de; FONSECA, André Isola. Op. cit., p. 14). 
2.2. O "tribunal orientado para a vítima" de Nils Christie como uma nova FORMA DE SOLUÇÃO DE CONFLITOS

Conforme verificado, Christie defendia a devolução ou a retomada dos conflitos do Estado à vítima e à sociedade. Como meio alternativo à justiça penal tradicional o autor propôs o que classificou como "tribunal orientado para a vítima" ${ }^{4}$, no qual a atenção deve ser voltada à vítima para possibilitar que ela própria, em conjunto aos demais membros da sociedade, participe e solucione o seu conflito. A vítima necessita de ser ouvida, precisa de alguém que a escute com "paciência e simpatia" 55 . Ao justificar esta proposta, o criminólogo afirma que há muito tempo possuímos o mesmo modo de fazer justiça no âmbito penal, embora não tenha o sistema tradicional demonstrado a sua eficácia (pois não cumpre verdadeiramente seus objetivos). Por esta razão, não teríamos muito a perder ao (tentar) aplicar novos métodos de solução de conflitos criminais. Como ainda não encontramos uma cura para o crime, poderíamos começar a aprender a conviver e a reagir com ele de outra forma, de acordo com os valores da sociedade e com o seu senso de justiça ${ }^{56}$.

O tribunal orientado para a vítima seria uma espécie de tribunal comunitário, uma nova maneira de olharmos o problema causado pelo crime, solucionando-o da maneira mais justa para a comunidade local, de acordo com os seus próprios valores. Esse novo mecanismo de solução de conflitos funcionaria em quatro estágios, cada qual com suas peculiaridades. ${ }^{57}$

O primeiro estágio seria o mais elementar dos quatro. Nele seria verificado se a lei realmente foi contrariada e o responsável por sua violação. ${ }^{58}$ Estabelecidas materialidade e autoria, seguir-se-ia ao próximo estágio.

O segundo estágio seria o de maior importância, por garantir a participação da vítima na solução do problema. Nesta etapa, em que $a$

${ }_{54}$ CHRISTIE, Nils. Conflicts as property... cit., p. 10 e ss.

55 Como afirma Sérgio Shecaira (SHECAIRA, Sérgio Salomão. Criminologia. $5^{a}$ ed. rev. São Paulo: Editora Revista dos Tribunais, 2013, p. 305).

56 CHRISTIE, Nils. Conflicts as property... cit., p. 9.

57 CHRISTIE, Nils. Conflicts as property... cit., p. 9.

58 CHRISTIE, Nils. Conflicts as property... cit., pp. 9-10; OLIVEIRA, Ana Sofia Schmidt de; FONSECA, André Isola. Op. cit., pp. 15-16. 
situação da vítima seria considerada, realizar-se-ia um relatório no qual a vítima descreveria o fato com todos os seus pormenores. Todos os detalhes deveriam ser narrados, independentemente de sua relevância jurídico-legal. Em seguida, as opções de reparação do dano causado à vítima seriam discutidas. Este momento deveria ser iniciado com a oitiva do ofensor, em seguida a dos membros do bairro ou comunidade, para só então ocorrer a intervenção de um representante do Estado. Embora possa a reparação assumir um caráter patrimonial - pagar o conserto de uma janela quebrada, por exemplo - , ela também poderia ser realizada de outras formas, como a reparação direta do dano pelo ofensor - consertando a janela, por exemplo - , ou então mediante outras vias não necessariamente relacionadas com o fato - como a prestação de serviços à comunidade.${ }^{59}$ Somente após uma séria ponderação sobre as informações obtidas nos estágios anteriores, sem preocupação com lapsos temporais, é que se avançaria ao terceiro estágio.

Apenas no terceiro estágio é que os julgadores deliberariam acerca da necessidade de aplicação de uma punição. Contudo, nestes tribunais comunitários a punição assumiria um caráter diferente: ela passa a ser considerada um sofrimento adicional àqueles sofrimentos construtivos não-intencionais causados pelas ações restitutivas em favor da vítima. Essa análise sobre a necessidade de uma punição adicional decorre da possibilidade de a comunidade local poder encarar a solução como injusta ou intolerável nos casos em que o dano fosse irreparável, seja pela recusa do ofensor ou em razão de impossibilidade de reparação do dano. ${ }^{60}$

No quarto estágio, após a decisão do tribunal comunitário, a atenção seria voltada ao ofensor. Nesta etapa todos os aspectos que dizem respeito à sua situação pessoal e à possibilidade de cumprimento dos acordos e/ ou da punição cominada seriam analisados e informados ao tribunal. Isso porque, em determinados casos, medidas sociais, educacionais, médicas ou até mesmo religiosas precisariam ser adotadas para viabilizar a solução do conflito. Contudo, Christie ressalta que tais medidas somente deveriam ser analisadas posteriormente à sentença, caso contrário correr-se-ia

59 CHRISTIE, Nils. Conflicts as property... cit., pp. 9-10; OLIVEIRA, Ana Sofia Schmidt de; FONSECA, André Isola. Op. cit., p. 15-16. 
o risco de fazer ressurgir as chamadas "medidas especiais" do sistema tradicional de justiça penal, as quais deveriam ser evitadas ao máximo. ${ }^{61}$

Através desses quatro estágios, os tribunais comunitários solucionariam os conflitos criminais mediante "uma mistura de elementos de tribunais civis e penais, mas com uma forte ênfase nos aspectos civis”"2, diferentemente do sistema atual de justiça penal.

Importante destacar que, para Nils Christie, a criação de novos tribunais ou a reordenação dos existentes é insuficiente, a real importância seria voltada à certificação de que os "tribunais orientados para a vítima" fossem operados por pessoas da própria comunidade, bairro ou vilarejo, evitando-se ao máximo a intervenção de pessoas especializadas ${ }^{63.64} \mathrm{O}$ tipo

61 CHRISTIE, Nils. Conflicts as property... cit., pp. 10-11; OLIVEIRA, Ana Sofia Schmidt de; FONSECA, André Isola. Op. cit., p. 16.

62 Tradução nossa. No original: "a blend of elements from civil and criminal courts, but with a strong emphasis on the civil side" (CHRISTIE, Nils. Conflicts as property... cit., p. 11).

63 De acordo com Christie, a importância de ser composto e operado por pessoas leigas e da própria comunidade decorreria do fato de a especialização, com o tempo, levar à profissionalização, o que acabaria por criar uma falsa ideia àqueles profissionais de que somente eles teriam a capacidade de resolver os conflitos, distanciando-os, em certo grau, da comunidade local. Destarte, advogados e assistentes sociais não seriam necessários, porém nas raras ocasiões em que a sua indispensabilidade fosse verificada a sua atuação deveria ser limitada à organização do conflito, jamais assumindo o seu controle. A atuação secundária de profissionais poderia ocorrer no primeiro estágio, por exemplo, no qual os expertos, de acordo com as suas especializações, poderiam verificar se o ofensor é mesmo o culpado pelo fato-problema ou então assegurar a não violação de seus direitos de defesa (CHRISTIE, Nils. Conflicts as property... cit., pp. 11-12. Ver também JOHNSTONE, Gerry; NESS, Daniel W. Van. The meaning of restorative justice. In: JOHNSTONE, Gerry; NESS, Daniel W. Van (eds.). Handbook of Restorative Justice. Cullompton: Willan Publishing, 2007, p. 9 e ss.; e SAWIN, Jennifer Larson; ZEHR, Howard. The ideas of engagement and empowerment. In: JOHNSTONE, Gerry; NESS, Daniel W. Van (eds.). Handbook of Restorative Justice. Cullompton: Willan Publishing, 2007, p. 42 e ss.). A limitação de terceiros especializados mitiga a "distância neutralizante" de que trata Bordieu (BORDIEU, Pierre. O poder simbólico. Tradução: Fernando Tomaz. Rio de Janeiro: Bertrand Brasil, 1989, p. 228), impede o monopólio do conflito e garante que a vítima, o ofensor e a sociedade participem no seu processo de solução.

64 Verificamos no modelo de Christie um problema acerca da representatividade da comunidade. Seguindo a interpretação de Christie, a participação da comunidade é voluntária. O voluntariado demanda a disponibilidade de 
ideal de justiça participativa seria aquele baseado no senso de justiça dos próprios participantes, que utilizariam os seus valores comunitários, o seu "dialeto legal local” ${ }^{65}$, para solucionar o problema. ${ }^{66} \mathrm{Com}$ isso, além de os participantes lidarem com o conflito de acordo com seu próprio senso de justiça, teriam também conhecimento dos acontecimentos daquela determinada localidade e dos problemas salientes em sua comunidade ${ }^{67}$.

Nessa espécie de justiça participativa os valores sociais não são esclarecidos através da dor, mas através do próprio processo participativo. A atenção do tribunal não se volta mais para o fim, para uma sentença penal, uma punição, mas sim para o próprio processo de solução do conflito. $\mathrm{O}$ esclarecimento de valores deixa de ser estabelecido pelo Estado através da intensidade de dor administrada pelo Direito Penal e passa a ser estabelecido pelo processo de busca de resultado na justiça participativa promovida pelos tribunais comunitários. ${ }^{68}$

tempo, o que tende a provocar uma distorção na representatividade da comunidade, pois, via de regra, os voluntários seriam membros que poderiam dispor de seu tempo sem se preocupar com responsabilidades e prejuízos diversos (como a ausência no trabalho ou então a necessidade de permanecer em casa para cuidar de filhos ou familiares), os quais podem não representar os membros daquela localidade. CHRISTIE, Nils. Limits to pain... cit., p. 114.

Atualmente, em um contexto social marcado pelo distanciamento, multiculturalidade e fluidez de valores, a aplicabilidade deste modelo de busca por uma solução ao conflito baseado no senso de justiça decorrente de valores comunitários parece se distanciar cada vez mais da realidade. Este modelo aparenta ter eficácia restrita a comunidades pequenas, nas quais as pessoas tendem a conhecer os seus vizinhos e os problemas que ocorrem na localidade. Isso não significa, contudo, afirmar que o modelo de Christie seja utópico. A justiça restaurativa atual precisa, na verdade, trabalhar com uma noção mais concreta e atual de comunidade. Mesmo que compartilhemos da ideia de que a participação de profissionais deva ser restrita à organização do conflito (em respeito ao empoderamento das partes), inegável reconhecer que o papel de experts ganha mais importância no contexto atual frente ao distanciamento e à pluralidade que marcam a sociedade hodierna. As pessoas especializadas, em virtude de suas atividades profissionais ou acadêmicas, tendem a conhecer mais sobre a realidade do local em que o conflito ocorreu do que as próprias pessoas que nele vivem.

67 CHRISTIE, Nils. Conflicts as property... cit., pp. 9-12. Ver também CHRISTIE, Nils. Limits to pain... cit., pp. 98-105.

CHRISTIE, Nils. Limits to pain... cit., pp. 92-98. 
Ao versar sobre a viabilidade de um sistema organizado nestes parâmetros, Christie afirma que o senso de justiça é inerente ao ser humano e se desenvolve a partir da interação social ${ }^{69}$. Embora em um primeiro momento este método alternativo de solução de conflitos pareça inexequível, o autor acredita que o desenvolvimento deste senso inerente de justiça e o fortalecimento dos valores locais seriam capazes de garantir a sua execução ${ }^{70}$. Quanto maior for a atuação do Estado, impondo dor sem se preocupar com a interação entre a sociedade e os envolvidos na situação-problema, maiores são as chances de o poder estatal encontrar meios capazes de perpetuar o sofrimento, pois, como afirma o criminólogo norueguês, "quanto mais Estado, mais condições são assentadas para a punição, quanto menos Estado, menos são as condições que encorajam a punição" ${ }^{\text {"11. }}$

Uma grande crítica a esse sistema de justiça participativa seria a sua eficácia e legitimidade quando a vítima ou o próprio subsistema tendesse a buscar soluções incompatíveis com o ordenamento jurídico estatal, como por exemplo o uso de tortura ou sanções desumanas ou degradantes. Nesses casos, as instituições estatais deveriam intervir para impedir soluções ilegais, o que cria um dilema reconhecido por Christie, pois ao mesmo tempo em que o autor busca alternativas ao poder punitivo estatal ele também reconhece que em hipóteses excepcionais a intervenção do Estado (e em certos casos do sistema tradicional penal) ainda é necessária para controlar possíveis crueldades. Contudo, a atuação estatal deveria ser sempre mínima ${ }^{72}$; a atuação penal menor ainda. ${ }^{73}$

69 CHRISTIE, Nils. Limits to pain... cit., p. 114. Em sentido semelhante, Braithwaite defende que a interação social e as disputas diárias contra injustiças permitem que as pessoas desenvolvam um sentido de democracia e civismo (BRAITHWAITE, John. Restorative Justice: Assessing Optimistic and Pessimistic Accounts. Crime and Justice, Chicago, v. 25, pp. 1-127, 1999, p. 77 e ss.). down for punishment, and the less State, the less the conditions encourage punishment" (CHRISTIE, Nils. Limits to pain... cit., p. 115).

72 "[S]o little State as we dare. So small systems as we dare. So independent systems as we dare. So egalitarian systems as we dare. So vulnerable participants as we dare" (CHRISTIE, Nils. Limits to pain... cit., p. 115).

73 CHRISTIE, Nils. Limits to pain... cit., pp. 92-116. 


\section{Contributos da teoria minimalista de Nils Christie para as PRÁTICAS RESTAURATIVAS PENAIS}

\subsection{A JustiçA RESTAURATIVA}

Além do questionamento acerca da pena de prisão (sua dor e seu sofrimento) e do sistema penal lato sensu, a leitura feita por Nils Christie - assim como a de seus colegas abolicionistas - sobre o sistema penal tradicional também permitiu a reflexão sobre a possibilidade de criação e aplicação de meios alternativos de solução de conflitos criminais, fomentando a busca por métodos e procedimentos capazes de contornar as máculas do sistema penal tradicional, como as práticas englobadas na justiça restaurativa ${ }^{74}$.

Estruturando-se sob as ideias de Nils Christie e sob as contribuições do abolicionismo penal, das teorias sociológicas do crime, da criminologia crítica e da Vitimologia ${ }^{75}$, a justiça restaurativa surge como uma nova perspectiva que visa romper ${ }^{76} \mathrm{com}$ o doloroso modus operandi do sistema de justiça criminal tradicional.

Desde a segunda metade do século $\mathrm{XX}^{77}$, com especial impulsão a partir dos anos $1990^{78}$, a justiça restaurativa vem se firmando como uma nova resposta ao conflito criminal, suas consequências e aos indivíduos nele envolvidos. Trata-se de uma perspectiva que busca afastar a tradição penal de monopólio estatal do processo de solução do conflito e devolver à vítima, ao ofensor e aos membros da comunidade o poder de participação direta e concreta na busca pela solução que julgam ser a

74 RUGGIERO, Vicenzo. The Legacy of ... cit.; RUGGIERO, Vicenzo. Penal Abolitionism: a celebration. Oxford: Oxford University Press, 2010, pp. 175-209. SANTOS, Cláudia Cruz. A justiça restaurativa... cit., p. 300.

76 Ruptura esta analisada pormenorizadamente na paradigmática obra de Howard Zehr intitulada "Changing lenses: a new focus for crime and justice" (cf. ZEHR, Howard. Changing lenses... cit., passim, especialmente capítulo 5).

77 GIAMBERARDINO, André Ribeiro. O confisco do... cit., p. 34.

78 JACCOUD, Mylène. Innovations pénales et justice réparatrice. Champ pénal/ Penal field. Disponível em: <https://journals.openedition.org/champpenal/1269>. Acesso em: 03 fev. 2019. 
mais justa para dirimir o conflito ${ }^{79}$, através da criação de sistemas dialogais de abordagem da situação-problema ${ }^{80}$.

O termo "justiça restaurativa", utilizado no contexto ocidental inicialmente por Albert Eglash ${ }^{81}$, reúne diferentes conceitos que variam de acordo com a perspectiva adotada ${ }^{82}$. A premissa fundamental da justiça restaurativa, como destaca Howard Zehr, é de que "o crime é uma violação de pessoas e relacionamentos. Ele cria obrigações de reparação. A justiça [restaurativa] envolve a vítima, o ofensor e a comunidade na busca de soluções que promovam reparação, reconciliação e reafirmação"83. A sintética definição conferida por Tony Marshall parece englobar os aspectos elementares da

79 SANTANA, Selma Pereira de; SANTOS, Carlos Alberto Miranda. A justiça restaurativa como política pública alternativa ao encarceramento em massa. Revista Brasileira de Políticas Públicas, Brasília, v. 8, n. 1, p. 227-242, 2018, p. 229; GIAMBERARDINO, André Ribeiro. O confisco do... cit., p. 35; UNITED NATIONS. Office on Drugs and Crime. Handbook on Restorative Justice Programmes. New York: United Nations, 2006, p. 5; JACCOUD, Mylène. Op. cit.

ROSENBLATT, Fernanda Fonseca. Lançando um olhar empírico sobre a justiça restaurativa: alguns desafios a partir da experiência inglesa. Revista Brasileira de Sociologia do Direito, Porto Alegre, v. 1, n. 2, p. 72-82, 2014, p. 73; GIAMBERARDINO, André Ribeiro. A construção social... cit., p. 101.

Como apontado por Mylène Jaccoud e André Giamberardino (JACCOUD, Mylène. Op. cit.; GIAMBERARDINO, André Ribeiro. O confisco do... cit., p. 34). Cf. EGLASH, Albert. Creative Restitution. A Broader Meaning for an Old Term. The journal of Criminal Law, Criminology and Police Science, Chicago, v. 48, n. 6, p. 619-622, 1958; EGLASH, Albert. Beyond Restitution: Creative Restitution. In: GALAWAY, Burt; HUDSON, Joe (eds.). Restitution in Criminal Justice. Lexington: Lexington Books, 1975, p. 91-101.

Sob a perspectiva minimalista (ou pura), a restauratividade é associada mais à participação das partes direta e indiretamente (comunidade) envolvidas no conflito do que ao acordo ou ao resultado. Esta perspectiva - voltada com especial atenção à reparação simbólica e não apenas à pecuniária — somente reconhece a reparação caso haja ao menos uma tentativa de promoção de encontro entre vítima e ofensor (e membros da comunidade ou familiares interessados), defendendo ainda que o envolvimento do Estado no processo de solução do conflito compromete e perverte os fundamentos da prática restaurativa. Já a perspectiva maximalista defende uma função reformista máxima (ou majoritária) da justiça penal (dentro e fora do sistema de justiça criminal) e confere ênfase à reparação dos danos pela via compensatória ou restitutiva, inclusive mediante coerção, preocupando-se mais com a reparação pecuniária (JACCOUD, Mylène. Op. cit.; GIAMBERARDINO, André Ribeiro. O confisco do... cit., p. 32).

83 Tradução nossa. No original: "Crime is a violation of people and relationships. It creates obligations to make things right. Justice involves the victim, the offender, 
justiça restaurativa: "justiça restaurativa é um processo em que todos os participantes envolvidos em uma ofensa específica se reúnem para decidir coletivamente como lidar com as consequências da ofensa e suas implicações para o futuro" ${ }^{\text {. }}$. Nas lições de Cláudia Cruz Santos, as finalidades das diferentes faces da intervenção restaurativa estão ligadas à "reparação dos danos originados pelo crime através de uma responsabilização voluntariamente assumida pelo agente" ${ }^{85}$, promovendo "um espaço de encontro" 86 que viabilize a participação e o contato entre os indivíduos envolvidos no conflito criminal $^{87}$, respeitando a autonomia da vontade individual das partes em procurar a solução que acreditam ser a mais justa para dirimir o conflito. Definições semelhantes são conferidas pela Organização das Nações Unidas ${ }^{88}$ e pelo Parlamento Europeu e o Conselho da União Europeia ${ }^{89}$.

and the community in a search for solutions which promote repair, reconciliation, and reassurance" (ZEHR, Howard. Changing lenses... cit., p. 181). Tradução nossa. No original: "Restorative justice is a process whereby all the parties with a stake in a particular offence come together to resolve collectively how to deal with the aftermath of the offence and its implications for the future" (MARSHALL, Tony. Op. cit., p. 37).

85 SANTOS, Cláudia Cruz. A justiça restaurativa... cit., p. 304. Nesse mesmo sentido, KERCHOVE, Michel van de. La justice restauratrice au cœur du conflit des paradigmes de la peine. Histoire de la justice, Paris, n. 25, p. 123-133, 2015, pp. 132-133. SANTOS, Cláudia. Um crime, dois... cit., p. 467.

Mesmo que conflitos de outra espécie possam ser solucionados através de práticas semelhantes às adotadas na justiça restaurativa - a exemplo da mediação realizada no âmbito cível - , no conceito e nas práticas de justiça restaurativa apenas há espaço para a solução de conflitos criminais (cf. SANTOS, Cláudia Cruz. A justiça restaurativa... cit., pp. 305-309; e FERREIRA, Francisco Amado. Op. cit., pp. 24-26).

88 “'Restorative process' means any process in which the victim and the offender, and, where appropriate, any other individuals or community members affected by a crime, participate together actively in the resolution of matters arising from the crime, generally with the help of a facilitator. Restorative processes may include mediation, conciliation, conferencing and sentencing circles" (ORGANIZAÇÃO DAS NAÇÕES UNIDAS. Conselho Econômico e Social. Resolução 2002/12, de 24 de julho de 2012. Disponível em: <http://www. un.org/en/ecosoc/docs/2002/resolution\%202002-12.pdf>. Acesso em: 01 fev. 2019; e UNITED NATIONS. Op. cit., p. 7)

89 "[U]m processo que permite que a vítima e o autor do crime participem ativamente, se o fizerem com o seu livre consentimento, na resolução de questões decorrentes do crime mediante a ajuda de terceiros imparciais" (artigo 
Em que pese polissêmica ${ }^{90}$, em sentido amplo a justiça restaurativa é caracterizada pelo empoderamento das partes diretamente afetadas pelo conflito e pela atenção às necessidades da vítima, à reintegração do ofensor e ao fortalecimento dos valores comunitários através de práticas ${ }^{91}$ que visem fazer justiça mediante a restauração do dano provocado por um crime ${ }^{92}$. Tem como uma de suas finalidades romper os paradigmas tradicionais de fundamentação da punição e ampliar os espaços de diálogo, integração e regulação social ${ }^{93}$.

É por isso que autores como Van Ness e Gerry Johnstone ${ }^{94}$ compreendem a justiça restaurativa como um movimento social (global) que tem como objetivo maior transformar o modo como as sociedades contemporâneas encaram e respondem ao crime e a outros comportamentos problemáticos a ele relacionados, através da tentativa de substituição

2. ${ }^{\circ}, 1$, “d” da Diretiva 2012/29/UE do Parlamento Europeu e do Conselho, de 25 de outubro de 2012. UNIÃO EUROPEIA. Parlamento Europeu e Conselho da União Europeia. Diretiva 2012/29/UE do Parlamento Europeu e do Conselho, de 25 de outubro de 2012. Disponível em: <https://eur-lex.europa.eu/ legal-content/PT/TXT/HTML/?uri=CELEX:32012L0029>. Acesso em: 01 fev. 2019).

90 Decorrente da complexidade do paradigma restaurativo, do dissenso doutrinário acerca de sua definição e objetivos, das terminologias utilizadas e do seu desenvolvimento em espaços geográficos distintos (cf. GIAMBERARDINO, André Ribeiro. O confisco do... cit., pp. 34-35 e ss.; UNITED NATIONS. Op. cit., p. 6).

91 Embora sejam múltiplas as modalidades de práticas restaurativas, as mais comuns são a mediação vítima-ofensor, as conferências e os círculos (RAYE, Barbara E.; ROBERTS, Ann Warner. Restorative processes. In: JOHNSTONE, Gerry; NESS, Daniel W. Van (eds.). Handbook of Restorative Justice. Cullompton: Willan Publishing, 2007, pp. 212-216; NESS, Daniel W. Van; STRONG, Karen Heetderks. Op. cit., pp. 26-30; SANTOS, Cláudia Cruz. A justiça restaurativa... cit., p. 633 e ss.; UNITED NATIONS. Op. cit., p. 66 e ss.).

PALI, Brunilda. Justiça ativa: Processos de justiça restaurativa como campo fértil para o exercício da cidadania. Sistema Penal \& Violência, Porto Alegre, v. 6, n. 1, p. 31-42, 2014, p. 36; WALGRAVE, Lode. La justice restaurative: à la recherche d'une théorie et d'un programme. Criminologie, Montréal, v. 32, n. 1, p. 7-29, 1999, p. 9; UNITED NATIONS. Op. cit., p. 2; ZEHR, Howard. Changing lenses... cit., p. 184 e ss.

JOHNSTONE, Gerry; NESS, Daniel W. Van. Op. cit., p. 5. 
do sistema tradicional de justiça penal por outras formas de solução de conflitos orientadas pela comunidade.

A justiça restaurativa é pautada por princípios fundamentais como a voluntariedade, o consentimento informado, a confidencialidade, a informalidade, o respeito mútuo, a honestidade e a pessoalidade ${ }^{95}$. Para Howard Zehr, o movimento restaurador está alicerçado em três pilares: a) atenção e foco ao dano causado; $b$ ) ciência de que danos conduzem a determinadas obrigações; e c) promoção do compromisso ou participação na reparação do dano produzido. ${ }^{96} \mathrm{~A}$ partir destes três princípios, Howard Zehr e Harry Mika elencam dez princípios (ou indicadores) a serem observados no planejamento e aplicação de práticas restaurativas. ${ }^{97}$

Walgrave e Bazemore destacam o que chamam de três "valores" a serem observados na justiça restaurativa: a) igualdade no tratamento de todas as partes envolvidas no processo restaurativo; $b$ ) busca pela

95 MORÃO, Helena. Justiça restaurativa e crimes patrimoniais. In: PALMA, Maria Fernanda; DIAS, Augusto Silva; MENDES, Paulo de Sousa (orgs.). Direito Penal económico e financeiro: conferências do curso pós-graduado de aperfeiçoamento. Coimbra: Coimbra Editora, 2012, p. 271; LLEWELLYN, Jennifer J.; HOWSE, Robert. Restorative Justice: A Conceptual Framework. Ottawa: Law Commission of Canada, 1999, p. 57 e ss.

ZEHR, Howard. The Little Book of Restorative Justice. Versão eletrônica. New York: Good Books, 2014, capítulo 2. Ver também ZEHR, Howard. Changing lenses... cit., p. 186 e ss.

97 São eles: 1) foco nos danos do crime e não nas regras violadas; 2) mostrar igual preocupação e compromisso com vítimas e ofensores, envolvendo ambos no processo de justiça; 3) trabalhar em prol da restauração das vítimas, empoderando-as e respondendo às suas necessidades quando constatadas pelas próprias vítimas; 4) apoio a ofensores, incentivando-os a entender, aceitar e cumprir suas obrigações; 5) reconhecer que, embora as obrigações possam ser difíceis ou pesadas para os ofensores, tais obrigações não devem ser impostas ou consideradas como dano e devem ser passíveis de cumprimento; 6) proporcionar oportunidades de diálogo, direto ou indireto, entre a vítima e o ofensor, conforme apropriado; 7) encontrar maneiras significativas de envolver a comunidade e responder às concepções comunitárias de crime; 8) incentivar a colaboração e a reintegração das vítimas e dos ofensores, ao invés da coerção e do isolamento; 9) dar atenção às consequências não-intencionais das ações e do programa; 10) mostrar respeito a todas as partes vítimas, ofensores e colegas do sistema de justiça (ZEHR, Howard. The Little Book... cit., capítulo 2). 
satisfação da vítima, do ofensor e da comunidade; e c) proteção legal dos indivíduos contra ações estatais injustificadas. ${ }^{98}$

Van Ness e Karen Strong, por sua vez, estabelecem como princípios fundamentais da justiça restaurativa: $a$ ) exigência de um trabalho voltado para a cura das vítimas, dos ofensores e das comunidades danificadas pelo crime; $b$ ) garantia de que as vítimas, os ofensores e a comunidade tenham a oportunidade de se envolver ativamente no processo de solução do conflito o mais cedo que desejarem e de forma plena; e c) necessidade de repensar os papéis e responsabilidades do governo e da comunidade, uma vez que na promoção da justiça o governo é o responsável por preservar uma ordem justa e a comunidade por estabelecer uma paz justa. ${ }^{99}$ Van Ness e Karen Strong também identificam quatro valores normativos $^{100}$ e dez valores operacionais na justiça restaurativa ${ }^{101}$.

98 BAZEMORE, Gordon; WALGRAVE, Lode. Restorative juvenile justice: in search of fundamentals and an outline for systemic reform. In: BAZEMORE, Gordon; WALGRAVE, Lode (eds.). Restorative Juvenile Justice: Repairing the Harm of Youth Crime. Monsey: Criminal Justice Press, 1999, p. 65.

NESS, Daniel W. Van; STRONG, Karen Heetderks. Op. cit., pp. 43-47.

${ }^{100}$ Os valores normativos são classificados pelos autores como o "modo como o mundo deveria ser". São eles: 1 ) responsabilidade ativa (tomar a iniciativa de ajudar a preservar e a promover valores restaurativos e a reparar comportamentos que prejudiquem outras pessoas); 2) vida social pacífica (responder ao crime de forma a promover a harmonia, contentamento, segurança e bem -estar da comunidade); 3) respeito (respeitar e tratar todas as partes envolvidas em um conflito criminoso como pessoas dotadas de dignidade e valor); e 4) solidariedade (experiência de apoio e conectividade mesmo em meio a divergências significativas ou diferenças) (NESS, Daniel W. Van; STRONG, Karen Heetderks. Op. cit., pp. 48-49).

101 Os valores operacionais são aqueles que deveriam servir como critérios básicos para o correto funcionamento das práticas restaurativas. São eles: 1) reparação (o responsável pelo dano decorrente da ofensa também é responsável por sua reparação); 2) assistência (as partes afetadas são auxiliadas conforme necessário para que possam se tornar membros contribuintes de suas próprias comunidades após o delito); 3) colaboração (as partes são encorajadas a encontrar soluções a partir da tomada de decisão mútua e consensual); 4) empowerment (as partes tem de ter uma oportunidade autêntica de participar e influenciar nas deliberações sobre a solução do conflito); 5) encontro (as partes devem poder se encontrar em um ambiente seguro para discutir a ofensa e proceder ao seu processo de solução); 6) inclusão (as partes diretamenta afetadas são convidadas a se engajar diretamente nas práticas restaurativas); 7) educação moral (reforço de normas e valores comunitários 
A Organização das Nações Unidas estabelece como valores da justiça restaurativa a) o tratamento respeitoso de todos os envolvidos; b) a promoção de participação e empoderamento de todas as partes interessadas; $c$ ) clareza e previsibilidade; e $d$ ) flexibilidade e responsividade às circunstâncias individuais de cada caso. ${ }^{102}$

Ao contrário do sistema tradicional de justiça criminal que provoca dor e sofrimento, na justiça restaurativa a punição é ressignificada e assume um caráter humanitário e integracionista. Nas práticas restaurativas, a punição pode adotar diferentes formas (compensação, reparação, reconciliação, retratação, prestação de serviços comunitários, entre outras), podendo ser diretas ou indiretas, concretas ou simbólicas, não necessariamente dirigidas à vítima. ${ }^{103}$

\subsection{A influência dos ideais de Nils Christie no atual PARADIGMA RESTAURATIVO}

O estudo da justiça restaurativa precedido da exposição pormenorizada do pensamento de Nils Christie permite a verificação da concretização de seus ideais no paradigma restaurativo.

Há na justiça restaurativa a preocupação com a integração social, identificada na tentativa de criação de espaços viáveis de encontro e diálogo que permitam aos envolvidos no conflito que conheçam uns aos outros como pessoas e não em razão do papel que desempenham na sociedade. A aproximação entre vítima, ofensor e comunidade permite que a realidade de cada um seja conhecida (suas crenças, seus valores, seus motivos, seus sofrimentos), diminuindo o distanciamento social observado por Christie. Trata-se, nesta acepção, de uma tentativa de repersonalização da vida social.

decorrente da interação entre as partes no processo restaurativo); 8) proteção (proteção emocional e física de todas as partes envolvidas no processo); 9) reintegração (às partes são conferidos meios e oportunidades de reintegração social); e 10) solução (os problemas relacionados à ofensa e as suas consequências são devidamente abordados e as pessoas envolvidas são apoiadas) (NESS, Daniel W. Van; STRONG, Karen Heetderks. Op. cit., p. 49).

${ }^{102}$ UNITED NATIONS. Op. cit., p. 9.

103 WALGRAVE, Lode. Op. cit., pp. 9-11; ZEHR, Howard. Changing lenses... cit., p. 210 e ss.; GIAMBERARDINO, André Ribeiro. A construção social... cit., p. 94. 
As práticas restaurativas impedem que as pessoas sejam avaliadas a partir de uma dicotomia simplista de que alguém tem de necessariamente perder e alguém necessariamente ganhar, como ocorre no atual sistema de justiça criminal. Através da voluntária participação, do compromisso e do empoderamento das partes, durante o processo de solução do conflito as práticas restaurativas permitem, pela via do diálogo, o reforço dos valores comunitários, a ressocialização e a efetiva reparação do dano, ideias profusamente defendidas por Christie. Reconhece-se a importância das possibilidades pedagógicas extraídas do processo de solução do conflito. Desta forma, sob a perspectiva restaurativa somente existem ganhadores. Essa aproximação entre as partes também rompe com a tendência da justiça criminal hodierna de tratar todos os casos como se iguais fossem, recuperando a singularidade de cada conflito.

A justiça restaurativa se preocupa, portanto, com a (tentativa de) devolução do conflito às partes; volta a atenção ao dano causado e à participação das partes no processo de solução do conflito, o qual se torna, por vezes, mais importante do que a sua própria solução, como defendido por Nils Christie. Trata com igualdade e devida preocupação tanto a vítima quanto o ofensor, respondendo às necessidades da vítima ao mesmo tempo em que incentiva o ofensor a compreender o dano provocado e a relevância do cumprimento de suas obrigações reparadoras. Permite a construção de uma solução considerada justa, adequada e satisfatória sob a ótica dos envolvidos e protege os indivíduos contra ações estatais injustificadas, ideais estes defendidos por Christie.

Ao apontar que a pena imposta pelo tradicional sistema de justiça criminal não é mais do que a imposição intencional de dor - e que a discussão sobre a punição é também uma discussão sobre a imposição de uma dor -, Christie abriu caminho para a formulação de métodos alternativos de solução de conflitos criminais. Embora não prescinda da punição, na perspetiva restaurativa a punição ganha um significado humanitário que se distancia da inflição de dor. Abre-se às partes a possibilidade de deliberação de soluções como a compensação, a retratação e a prestação de serviços comunitários como modo de formalizar e materializar o juízo de reprovação. Trata-se de uma tentativa de cura, uma tentativa humana de efetiva reparação do impacto e das consequências (individuais e comunitárias) provocados pelo conflito. 
No paradigma restaurativo há, portanto, o reconhecimento de que a pena é um mal (um sofrimento) e de que reagir ao mal representado pelo crime com o mal da pena não significa nada mais que a própria perpetuação do mal ${ }^{104}$, a inflição de mais sofrimento, sem qualquer encerramento verdadeiramente satisfatório e humanitário para o conflito. Isso porque a pena de prisão ou a pena de multa não reparam o dano sofrido pela vítima, por se tratarem, assim como defendido por Christie, de sanções estranhas aos envolvidos na ofensa.

Somente através das práticas restaurativas é que poderiam ser concretizados aqueles objetivos inicialmente prometidos, porém reconhecidamente não cumpridos, pelo sistema penal tradicional. Somente através da justiça restaurativa é que há a possibilidade de conferir uma experiência significativa de justiça para as vítimas e a cura de traumas que elas usualmente sofrem. Somente as práticas restaurativas viabilizam o verdadeiro empoderamento das partes; a reconciliação; a verdadeira responsabilização do infrator; a reintegração do ofensor à sociedade (ressocialização); a efetiva reparação do dano (reparação simbólica, patrimonial, econômica ou social); e a regeneração comunitária.

\subsection{Notas sobre a mediação penal de adultos em Portugal}

A justiça restaurativa tende a ganhar mais legitimidade e produzir os efeitos almejados pelos seus defensores quando amparada por previsão legal. ${ }^{105}$ Os exemplos de justiça restaurativa bem-sucedidos que mais se destacam atualmente - inspirados pela matriz da criminologia crítica, do abolicionismo penal e do minimalismo de Nils Christie - são os modelos belga, neozelandês e norueguês ${ }^{106}$.

\footnotetext{
104 SANTOS, Cláudia. Um crime, dois..., cit., p. 463.

105 ACHUTTI, Daniel Silva. Justiça Restaurativa e... cit., pp. 185-186.

${ }^{106}$ Cf. NESS, Daniel W. Van; STRONG, Karen Heetderks. Op. cit., p. 30 e ss. Para mais informações sobre o modelo belga, o modelo neozelandês e o modelo norueguês, cf., respectivamente, SHAPLAND, Joanna; CRAWFORD, Adam; GRAY, Emily; BURN, Daniel. Learning lessons from Belgium and Northern Ireland. Sheffield: University of Sheffield, 2017; NEW ZEALAND. Ministry of Justice. Restorative justice: best practice framework. Wellington: National Office, 2017; NESS, Daniel W. Van; STRONG, Karen Heetderks. Op. cit., pp. 26-28, 34, 155-156.
} 
No Brasil, embora as práticas restaurativas sejam empregadas há mais de dez anos para a solução de conflitos criminais (em sua maior parte de menor potencial ofensivo) ${ }^{107}$, são tímidos e lentos os passos trilhados para a implementação de práticas restaurativas na ordem jurídica interna. A justiça restaurativa não possui previsão legal no ordenamento jurídico brasileiro. O Projeto de Lei da Câmara dos Deputados n. ${ }^{0} 7006 / 2006^{108} \mathrm{e}$ as recomendações que constam na Resolução 225 do Conselho Nacional de Justiça, de 31 de maio de $2016^{109}$, destacam-se como os instrumentos

${ }^{107}$ De acordo com o Conselho Nacional de Justiça (cf. BRASIL. Conselho Nacional de Justiça. Justiça Restaurativa: horizontes a partir da Resolução CNJ 225. Brasília: CNJ, 2016, p. 20).

Rafaella Pallamolla aponta que as primeiras experiências oficiais de justiça restaurativa no Brasil ocorreram em 2005, com a criação e implementação do projeto "Promovendo Práticas Restaurativas no Sistema de Justiça Brasileiro", organizado pelo Ministério da Justiça, Secretaria Nacional de Direitos Humanos e pelo Programa das Nações Unidas para o Desenvolvimento, aplicado nas cidades de Porto Alegre/RS, São Caetano do Sul/SP e Brasília/DF (PALLAMOLLA, Raffaella da Porciuncula. A mediação penal no Brasil: presente e futuro. In: MELLO, Kátia Sento Sé; BAPTISTA, Bárbara Gomes Lupetti; FILPO, Klever Paulo Leal (orgs.). Potencialidades e incertezas de formas não violentas de administração de conflitos no Brasil e na Argentina. Porto Alegre: Evangraf, 2018, p. 143).

No Brasil, os "círculos de pacificação" (ou "círculos de construção de paz") são as práticas restaurativas penais mais aplicadas atualmente (PALLAMOLLA, Raffaella da Porciuncula. A mediação penal... cit., pp. 146-153). Tratam-se de práticas inicialmente desenvolvidas em 1991 por Barry Stuart, juiz do Yukon Territorial Court (Canadá), inspiradas nas tradições nativas e aborígenas de tribos da América do Norte e da Oceania de utilização de "círculos" para a solução de diferentes tipos de conflito. Os círculos foram adaptados por Barry Stuart ao sistema de justiça criminal e posteriormente aperfeiçoados por Kay Pranis, hoje considerada referência mundial nesta modalidade de prática restaurativa (NESS, Daniel W. Van; STRONG, Karen Heetderks. Op. cit., pp. 29-30; PARKER, Lynette. Circles. Centre for Justice \& Reconciliation. Disponível em: <http://restorativejustice.org/restorative-justice/about-restorative-justice/tutorial-intro-to-restorative-justice/lesson-3-programs/circles/>. Acesso em: 30 jan. 2019).

${ }^{108}$ BRASIL. Câmara dos Deputados. Projeto de Lei PL 7006/2006. Disponível em: <https://www.camara.gov.br/proposicoesWeb/fichadetramitacao?idProposicao=323785 $>$. Acesso em: 26 nov. 2018.

${ }^{109}$ Que “dispõe sobre a Política Nacional de Justiça Restaurativa no âmbito do Poder Judiciário" e evidencia a importância e a necessidade de implementação e aplicação de práticas restaurativas no Brasil (BRASIL. Conselho Nacional de Justiça. Resolução 225, de 31 de maio de 2016. 
jurídicos mais relevantes na implementação de práticas restaurativas no cenário jurídico brasileiro.

Uma das mais recentes positivações de justiça restaurativa no contexto mundial é a mediação penal "de adultos" em Portugal. A mediação penal de adultos - apesar de não ser a única prática restaurativa no ordenamento jurídico português ${ }^{110}$ - encontra previsão legal na Lei n. ${ }^{\circ}$ 21/2007, de 12 de Junho (a qual transpôs a Decisão-Quadro n. ${ }^{\circ}$ 2001/220/JAI, do Conselho, de 15 de Março para o ordenamento jurídico português).

Nos debates parlamentares da proposta de lei que deu origem à mediação penal de adultos, pontuou-se a pretensão de criar um sistema de mediação penal "assente num processo informal e flexível, conduzido por um terceiro imparcial, o mediador, que promove a aproximação entre o arguido e o ofendido" 111 , com a finalidade de apoiá-los a "encontrar activamente um acordo que permita a reparação — não necessariamente

Disponivel em: <http://www.cnj.jus.br/images/atos_normativos/resolucao/ resolucao_225_31052016_02062016161414.pdf>. Acesso em: 28 nov. 2018).

${ }^{110}$ Outro exemplo de prática restaurativa no âmbito penal português é aquele voltado à "delinquência juvenil", regulamentado pela "Lei Tutelar Educativa" (Lei n. ${ }^{\circ}$ 166/99, de 14 de Setembro).

${ }^{111}$ PORTUGAL. Assembleia da República. Proposta de Lei n. ${ }^{o}$ 107/X: Relatório, conclusões e parecer da Comissão de Assuntos Constitucionais, Direitos, Liberdades e Garantias. Disponível em: <http://debates.parlamento.pt/catalogo/r3/dar/s2a/10/02/047/2007-02-23/30?pgs=30-35\&org=PLC>. Acesso em: 28 jan. 2019, pp. 30-31.

Cumpre destacar que o(a) mediador(a) penal deve preencher os seguintes requisitos previstos no artigo $12 .^{\circ}$ da Lei n. $.^{\circ} 21 / 2007$, de 12 de Junho: Artigo 12. ${ }^{\circ}$ : 1 - As listas de mediadores penais são preenchidas mediante um procedimento de selecção, podendo candidatar-se quem satisfizer os seguintes requisitos: a) Ter mais de 25 anos de idade; b) Estar no pleno gozo dos seus direitos civis e políticos; c) Ter licenciatura ou experiência profissional adequadas; d) Estar habilitado com um curso de mediação penal reconhecido pelo Ministério da Justiça; e) Ser pessoa idónea para o exercício da actividade de mediador penal; f) Ter o domínio da língua portuguesa. 2 - Entre outras circunstâncias, é indiciador de falta de idoneidade para inscrição nas listas oficiais o facto de o requerente ter sido condenado por sentença transitada em julgado pela prática de crime doloso".

A atividade do mediador penal é remunerada (artigo $13 .^{\circ}$ da Lei n. ${ }^{\circ} 21 / 2007$, de 12 de Junho) e deve observar os deveres de imparcialidade, independência, confidencialidade e diligência (artigo $10 .^{\circ}$ da referida lei). 
pecuniária - dos danos causados pelo facto ilícito e contribua para a restauração da paz social"112.

A mediação penal de adultos tem aplicação em qualquer uma das fases do inquérito ${ }^{113}$, por iniciativa do Ministério Público (sempre que verificados os pressupostos do artigo $3 .^{\circ}$, n. ${ }^{\circ} 1$, da Lei n. ${ }^{\circ} 21 / 2007$, de 12 de Junho ${ }^{114}$ ) ou do ofendido e arguido (réu) (artigo $3 .^{\circ}$, n. $^{\circ} 2^{115}$ ). Trata-se de uma prática restaurativa restrita aos crimes particulares em sentido estrito e aos crimes semipúblicos ${ }^{116}$ contra as pessoas ou contra o patrimônio (artigo 2. ${ }^{\circ}$, n. os 1 e 2). Independentemente da natureza do crime, não podem ser remetidos para mediação casos em que: “a) o tipo legal de crime preveja pena de prisão superior a 5 anos; b) se trate de processo por crime contra a liberdade ou autodeterminação sexual; c) se trate de processo por crime de peculato, corrupção ou tráfico de influência; d) o ofendido seja menor de 16 anos; e) seja aplicável processo sumário ou sumaríssimo" (artigo 2. ${ }^{\circ}$, n. ${ }^{\circ} 3$ ).

Consoante os artigos $3 .^{\circ}$ e $4 .^{\circ}$ da Lei n. ${ }^{\circ} 21 / 2007$, de 12 de Junho, a mediação penal depende do consentimento do ofendido e do réu; é conduzida por um terceiro imparcial (mediador); é caracterizada por sessões de caráter confidencial, "informal e flexível"; e tem como finalidade auxiliar as partes a encontrar um acordo que permita a reparação dos

112 PORTUGAL. Assembleia da República. Proposta de Lei... cit., p. 31.

${ }^{113}$ Em Portugal, o inquérito tem natureza judicial e, com exceção aos casos previstos em lei, é indispensável (cf. artigos 262 e seguintes do Código de Processo Penal Português).

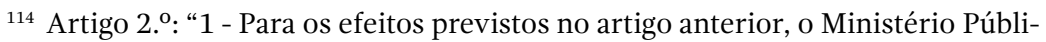
co, em qualquer momento do inquérito, se tiverem sido recolhidos indícios de se ter verificado crime e de que o arguido foi o seu agente, e se entender que desse modo se pode responder adequadamente às exigências de prevenção que no caso se façam sentir, designa um mediador das listas previstas no artigo $11 .^{\circ}$ e remete-lhe a informação que considere essencial sobre o arguido e o ofendido e uma descrição sumária do objecto do processo" (destaques nossos).

115 Artigo 2. ${ }^{\text {o: }}$ "2 - Se o ofendido e o arguido requererem a mediação, nos casos em que esta é admitida ao abrigo da presente lei, o Ministério Público designa um mediador nos termos do número anterior, independentemente da verificação dos requisitos aí previstos".

${ }^{116}$ Crimes cuja instauração da ação penal dependem de queixa de pessoa legitimada para prestá-la. 
danos causados. Nas sessões de mediação, as partes devem comparecer pessoalmente, podendo ser acompanhadas por advogado (artigo $8 .^{\circ}$ ).

A mediação penal de adultos rege-se, portanto, "pelos princípios fundamentais do consentimento informado, da confidencialidade, da informalidade e da pessoalidade" ${ }^{117}$. Depende da verificação da vontade das partes em participar no procedimento de mediação e do comparecimento pessoal dos envolvidos no conflito, sem possibilidade de representação (exceto nos casos em que o ofendido seja pessoa jurídica, não possuir discernimento para compreender o sentido da queixa ou ter morrido sem renunciar à queixa). O processo de mediação não é regulamentado, porém deve obedecer a ética e a deontologia profissional da atividade de mediação em Portugal. Todo o teor das sessões é confidencial, as informações obtidas durante o procedimento não podem ser valoradas como prova em processo judicial (por força do artigo $4 .^{\circ}$, n..$^{\circ} 5$ e artigo $10{ }^{\circ}$, n. $.^{o s} 3,4$ e 5 ). ${ }^{118}$

Ao final do encontro restaurativo, as partes têm autonomia para estabelecer a solução do problema através de um acordo, nos moldes que desejarem, desde que celebrado mediante seu expresso consentimento. O acordo não pode possuir natureza de "sanções privativas da liberdade ou deveres que ofendam a dignidade do arguido ou cujo cumprimento se deva prolongar por mais de seis meses" (artigo 6. ${ }^{\circ}$ ). Celebrado o acordo, este é reduzido a termo, assinado pelas partes e remetido pelo mediador ao Ministério Público (artigo $5^{\circ}$, n. ${ }^{\circ} 3$ ), que verificará a sua adequação com as disposições previstas na Lei n. ${ }^{\circ} 21 / 2007$, de 12 de Junho e homologará a desistência da queixa no prazo de cinco dias (artigo $5 .^{\circ}$, n. $^{\text {os }}$ 3 e 4). O descumprimento do acordo nos prazos fixados possibilita ao ofendido a renovação da queixa dentro do prazo de um mês, o que resulta na reabertura do inquérito (artigo $5 .^{\circ}$, n. ${ }^{\circ} 4$ ).

Apesar de representar um significativo avanço no que tange à tentativa de implementação de práticas restaurativas no sistema de justiça criminal, ao mesmo tempo em que (tenta) se aproxima(r) de muitos dos fundamentos do paradigma restaurativo e dos ideais defendidos por Nils Christie, a mediação penal de adultos também acaba por se afastar

\footnotetext{
117 MORÃO, Helena. Op. cit., p. 271 (destaques no original).

118 Para mais informações acerca do funcionamento do procedimento de mediação penal de adultos em Portugal, cf. MORÃO, Helena. Op. cit., pp. 271 e ss.
} 
de premissas básicas da justiça restaurativa, característica que suscita diferentes críticas na doutrina portuguesa.

A primeira grande crítica é a baixa adoção desta prática restaurativa. A título de ilustração, de acordo com os dados do Sistema de Informação das Estatísticas da Justiça do governo português ${ }^{119}$, entre o período de 2017 e o primeiro semestre de 2018 não houve registro de nenhum pedido ou movimento de processos de mediação penal em Portugal. Em 2016 somente foram registrados 6 procedimentos; e em 2015 foram registrados 34 procedimentos. Sem dúvida que a restrição do seu âmbito de aplicação (crimes particulares em sentido estrito e crimes semipúblicos contra as pessoas ou contra o patrimônio), a necessidade de consenso de ambas as partes para remessa à mediação por sua iniciativa e os demais requisitos contidos na Lei n. ${ }^{o} 21 / 2007$, de 12 de Junho impactam a quantidade de processos a serem remetidos à mediação, porém mesmo considerando-se todos estas limitações as estatísticas demostram a sua diminuta aplicabilidade no sistema de justiça criminal português.

A limitação do âmbito de aplicação da mediação penal de adultos aos crimes particulares em sentido estrito e aos crimes semipúblicos contra as pessoas ou contra o patrimônio também não está livre de críticas, seja porque, como defende Cláudia Cruz Santos, nos crimes públicos também há a possibilidade de "existir um conflito com a dimensão pessoal ou interpessoal carecido de uma possibilidade de pacificação" ${ }^{120}$; seja pela atecnia legislativa na redação do artigo $2 .^{\circ 121}$; ou então por ir contra os

119 PORTUGAL. Direção-Geral da Política de Justiça. Sistema de Informação das Estatísticas da Justiça. Estatísticas Oficiais da Justiça. Disponível em: <http:// www.siej.dgpj.mj.pt>. Acesso em: 02 fev. 2019.

${ }^{120}$ SANTOS, Cláudia Cruz. A justiça restaurativa... cit., p. 675.

121 “[Q]uando o legislador reportou aos crimes 'contra a pessoa', deveria ter antes feito referência a crimes 'que afectem bens jurídico-penais pessoais'. (...) O problema coloca-se de forma mais evidente, a nosso ver, na última parte do n. ${ }^{\circ} 2$ do artigo $2 .^{\circ}$, quando é limitada a mediação penal, no que aos crimes semi-públicos diz respeito, aos crimes 'contra o patrimônio'. De que património se trata? Estamos em crer que o legislador pretende englobar, sob tal expressão, tanto a propriedade em particular como o património em geral sendo, portanto, de aceitar a mediação penal por exemplo para os crimes de furto ou de dano. Tratando-se, assim, de uma noção lata de património, aceitaremos, a título exemplificativo e para além daqueles dois crimes, que a burla ou a emissão de cheque sem provisão possam conduzir à resolução da 
fundamentos do paradigma restaurativo e dos ideais de Nils Christie de ampliação do âmbito de aplicação das práticas restaurativas.

Apesar do esforço do legislador português, a integração ${ }^{122}$ da mediação penal de adultos ao processo penal não permite que esta prática seja considerada uma verdadeira ruptura do monopólio estatal do processo de solução do conflito, como defendia Christie, pois este ainda se encontra submetido ao controle do Ministério Público.

Além de não prever a participação de membros da comunidade ou de profissionais facilitadores na organização do conflito além do próprio mediador penal (como assistentes sociais ou psicólogos) ${ }^{123}$, a legislação dificulta a remessa do conflito à mediação penal por iniciativa do ofendido e do arguido, por neste caso requerer o consenso de ambas as partes (artigo 2. ${ }^{\circ}$, n. ${ }^{\circ}$ 2), contrariando os ideais defendidos por Nils Christie e os fundamentos da justiça restaurativa de autonomia da vítima e do ofensor.

Há de se destacar, contudo, o mérito do legislador ao conferir liberdade de fixação do acordo às partes, podendo a punição assumir natureza não somente material mas principalmente simbólica, bem como por impedir a inflição de dor ao proibir punições incompatíveis com o ideal restaurativo.

\section{Considerações finaIS}

As teorias desenvolvidas por Nils Christie contribuíram para o questionamento e uma nova visão sobre o funcionamento do sistema de justiça penal tradicional. Se, no início desta investigação, questionávamo-nos

questão por via da mediação. Coloca-se, então, a questão de saber o que fica

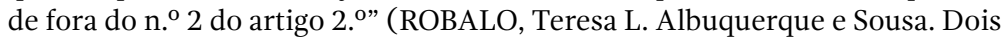
modelos de justiça restaurativa: a mediação penal (adultos) e os family group conferences (menores e jovens adultos). Revista Portuguesa de Ciência Criminal, Coimbra, A. 22, n. 1, p. 79-128, 2012, pp. 92-93. Ver, na mesma obra, p. 91 e ss. para mais críticas referente à atecnia legislativa).

${ }^{122}$ MORÃO, Helena. Op. cit., p. 272.

${ }^{123}$ Embora o artigo 8. ${ }^{\circ}$ faculte às partes a possibilidade de serem acompanhadas por seus advogados, acreditamos que a atuação destes profissionais deve ser restrita à organização do conflito - para usar a terminologia de Christie assegurando a não violação de direitos do seu representado e esclarecendo eventuais questões jurídico-legais, jamais interferindo de maneira direta no processo de solução do conflito. 
acerca da exequibilidade de métodos alternativos de solução de conflitos criminais, agora não nos restam mais dúvidas: a partir das ideias de Nils Chrsite verificamos serem as práticas restaurativas plenamente exequíveis.

Encontramos no minimalismo de Nils Christie a plena possibilidade de desenvolvimento de práticas restaurativas que pretendam romper com a dor e com o sofrimento causados pelo modelo tradicional de justiça penal. O conflito criminal não precisa necessariamente ser solucionado com a aplicação de dor e sofrimento inerentes ao processo penal e à cominação de uma pena de prisão. Diante do manifesto fracasso do sistema penal, premente a necessidade de examinarmos o conflito criminal e os seus meios de solução sob uma ótica diversa, em que as próprias partes participem no processo de solução do problema, construindo a solução que julgam mais justa a partir do diálogo e mútua compreensão.

A justiça restaurativa, influenciada por muitos dos ideais de Nils Christie, surge como uma valiosa possibilidade de aprendizado para a vítima, para que ela conheça o seu ofensor e os motivos que o levaram a praticar o injusto. É também uma possibilidade de aprendizado para o ofensor, o qual pode encontrar na prática restaurativa a sua redenção e oportunidades de reabilitação e ressocialização. As práticas restaurativas possibilitam que o ser humano seja visto como uma pessoa complexa que interage com outros indivíduos complexos, criando suas próprias regras e fazendo justiça de acordo com seus valores e experiências de vida.

Compensação, cura, crescimento pessoal, restauração, transformação, hospitalidade, solidariedade, empatia, responsabilidade e empoderamento das partes são noções basilares que devem nortear os meios alternativos para a solução do conflito, de modo a impedir a resposta automática da pena de prisão (ou de qualquer outra forma de sanção retributiva ou aflitiva) para os conflitos criminais.

Ainda não conseguimos superar o tradicional modelo de persecução e punição penal, porém, lentamente e com muito esforço, trilhamos em busca de novos meios de solução de conflitos criminais, como ocorre com as iniciativas de positivação da justiça restaurativa no Brasil e com a mediação penal de adultos em Portugal. Concretizam-se, aos poucos, os legados deixados por Nils Christie, sobretudo a necessidade de procurarmos alternativas à punição e não somente punições alternativas. Já é hora de trocarmos as lentes e apostarmos em meios alternativos mais 
humanitários para solução dos problemas tradicionalmente submetidos ao sistema penal, de modo a eliminarmos a imposição intencional de dor e permitir a construção de uma solução considerada justa, adequada e satisfatória sob a ótica dos envolvidos.

Os ideais de Nils Christie não devem ser considerados inexequíveis. Devem, no mínimo, servir como uma bússola que aponta para formas mais humanas de solução do conflito criminal, formas que possibilitem que extirpemos a inflição de dor do sistema de justiça criminal.

\section{REFERÊNCIAS}

ACHUTTI, Daniel Silva. Justiça Restaurativa e Abolicionismo Penal. São Paulo: Saraiva, 2014.

ACHUTTI, Daniel. Justiça restaurativa no Brasil: possibilidades a partir da experiência belga. Civitas, Porto Alegre, v. 13, n. 1, p. 154-181, 2013. https://doi. org/10.15448/1984-7289.2013.1.13344

ALVESALO-KUUSI, Anne; BITTLE, Steven; LÄHTEENMÄKI, Liisa. Corporate Criminal Liability and Abolitionism - An unholy alliance of corporate power and critical criminology?. Justice, Power and Resistance, London, v. 1, n. 1, p. 24-46, 2017.

ANDRADE, Manuel da Costa; DIAS, Jorge de Figueiredo. Criminologia: O Homem Delinquente e a Sociedade Criminógena. Coimbra: Coimbra Editora, 2013.

ANDRADE, Vera Regina Pereira de. Pelas mãos da criminologia: o controle penal para além da (des)ilusão. Rio de Janeiro: Revan, 2012.

ÁVILA, Gustavo Noronha de. O debate entre Luigi Ferrajoli e os abolicionistas: entre a sedução pelo discurso do medo e as práticas libertárias. Revista Jurídica Cesumar, São Paulo, v. 16, n. 2, p. 543-561, 2016. https://doi. org/10.17765/2176-9184.2016v16n2p543-561

BAILONE, Matías. En busca de una sensata cantidad de abolicionismo: de la conciencia política al desarrollo académico. In: POSTAY, Maximiliano E. (comp.). El abolicionismo penal en América Latina: imaginación no punitiva y militancia. Buenos Aires: Editores del Puerto, 2012, p. 85-108.

BAZEMORE, Gordon; WALGRAVE, Lode. Restorative juvenile justice: in search of fundamentals and an outline for systemic reform. In: BAZEMORE, Gordon; WALGRAVE, Lode (eds.). Restorative Juvenile Justice: Repairing the Harm of Youth Crime. Monsey: Criminal Justice Press, 1999, p. 45-74. 
BECKER, Howard Saul. Outsiders: estudos de sociologia do desvio. Tradução: Maria Luiza X. de A. Borges. Rio de Janeiro: Jorge Zahar Editora, 2008.

BIANCHI, Herman Thomas. Abolitionism in the Past, Present and Future. In: LASOCIK, Zbigniew; PLATEK, Monika; RZEPLIÂNSKA, Irena (Ed.). Abolitionism in History: On Another Way of Thinking. Warszawa: Instytut Profilaktyki Spolecznej i Resocjalizacji Uniwersytetu Warszawskiego, 1991.

BORDIEU, Pierre. O poder simbólico. Tradução: Fernando Tomaz. Rio de Janeiro: Bertrand Brasil, 1989.

BRAITHWAITE, John. Restorative Justice and Responsive Regulation. Oxford: Oxford University Press, 2002.

BRAITHWAITE, John. Restorative Justice: Assessing Optimistic and Pessimistic Accounts. Crime and Justice, Chicago, v. 25, pp. 1-127, 1999. https://doi. org/10.1086/449287

BRASIL. Câmara dos Deputados. Projeto de Lei PL 7006/2006. Disponível em: <https://www.camara.gov.br/proposicoesWeb/fichadetramitacao?idProposicao $=323785>$. Acesso em: 26 nov. 2018.

BRASIL. Conselho Nacional de Justiça. Justiça Restaurativa: horizontes a partir da Resolução CNJ 225. Brasília: CNJ, 2016.

BRASIL. Conselho Nacional de Justiça. Resolução 225, de 31 de maio de 2016. Disponivel em: <http://www.cnj.jus.br/images/atos_normativos/resolucao/ resolucao_225_31052016_02062016161414.pdf>. Acesso em: 28 nov. 2018.

BURGH, Richard W. Do the Guilty Deserve Punishment?. The Journal of Philosophy, [S. 1.], v. 79, n. 4, p. 193-210, 1982. https://doi.org/10.2307/2026220

CARRIER, Nicolas; PICHÉ, Justin. The State of Abolitionism. Champ Pénal/Penal Field, Paris, v. XXI, 2015. https://dx.doi.org/10.4000/champpenal.9164

CHRISTIE, Nils. Conflicts as property. The British Journal of Criminology, London, v. 17, n. 1, p. 1-15, 1977. https://doi.org/10.1093/oxfordjournals.bjc.a046783

CHRISTIE, Nils. Images of man in modern penal law. Contemporary Crises, Dordrecht, v. 10, n. 1, p. 95-106, 1986. https://doi.org/10.1007/BF00728498

CHRISTIE, Nils. Limits to Pain: The Role of Punishment in Penal Policy. Eugene: Wipf and Stock Publishers, 2007.

CHRISTIE, Nils. Victim Movements at a crossroad. Punishment \& Society, London, v. 12, n. 2, p. 115-122, 2010. https://doi.org/10.1177\%2F1462474509357978

CHRISTIE, Nils. A indústria do Controle do Crime: a caminho dos GULAGs em estilo ocidental. Tradução: Luís Leiria. Rio de Janeiro: Forense, 1998. 
CHRISTIE, Nils. Uma razoável quantidade de crime. Tradução, apresentação e notas: André Nascimento. $1^{\mathrm{a}}$ reimpr. Rio de Janeiro: Editora Revan, 2013.

COHEN, Stan. Introducción. In: CIAFARDINI, Mariano Alberto; BONDANZA, Mirta Lilián (orgs.). Abolicionismo Penal. Buenos Aires: Ediar Sociedad Anonima Editora, Comercial, Industrial y Financiera, 1989, p. 13-14.

DEVOTO, Eleonora; JULIANO, Mario Alberto. Un sistema penal alternativo. Hacia la abolición de la violencia institucional. In: POSTAY, Maximiliano E. (comp.). El abolicionismo penal en América Latina: imaginación no punitiva y militancia. Buenos Aires: Del Puerto, 2012, p. 109-116.

DIGNAN, James. Understanding victims and restorative justice. Maidenhead: Open University Press, 2005.

EGLASH, Albert. Creative Restitution. A Broader Meaning for an Old Term. The journal of Criminal Law, Criminology and Police Science, Chicago, v. 48, n. 6, p. 619-622, 1958. https://doi.org/10.2307/1140258

EGLASH, Albert. Beyond Restitution: Creative Restitution. In: GALAWAY, Burt; HUDSON, Joe (eds.). Restitution in Criminal Justice. Lexington: Lexington Books, 1975, p. 91-101.

FERREIRA, Francisco Amado. Justiça Restaurativa: Natureza, Finalidades e Instrumentos. Coimbra: Coimbra Editora, 2006.

GIAMBERARDINO, André Ribeiro. O confisco do conflito na histografia penal. Revista Eletrônica Direito e Sociedade, Canoas, v. 6, n. 2, p. 23-39, 2018. https:// doi.org/10.18316/redes.v6i2.3483

GIAMBERARDINO, André Ribeiro. A construção social da censura e a penologia um passo além: reparação criativa e restauração. Sistema Penal \& Violência, Porto Alegre, v. 6, n. 1, p. 88-102, 2014. https://doi.org/10.15448/2177-6784.2014.1.16650

HULSMAN, Louk; CELIS, Jacqueline Bernat de. Penas Perdidas: O Sistema Penal em Questão. Tradução: Maria Lúcia Karam. 2a ed. Niterói: Luam, 1997.

HULSMAN, Louk. El enfoque abolicionista: politicas criminales alternativas. In: RODENAS, Alejandra; FONT, Enrique Andrés; SAGARDUY, Ramiro A. P. (dirs.). Criminologia Critica y Control Social: 1. "El Poder Punitivo del Estado". Rosario: Juris, 1993, p. 75-104.

HULSMAN, Louk H. C. Critical criminology and the concept of crime. Contemporary Crises, Amsterdam. v. 10, p. 63-80, 1986. https://doi.org/10.1007/BF00728496 JACCOUD, Mylène. Innovations pénales et justice réparatrice. Champ pénal/Penal field. Disponível em: <https://journals.openedition.org/champpenal/1269>. Acesso em: 03 fev. 2019. https://doi.org/10.4000/champpenal.1269 
JOHNSTONE, Gerry; NESS, Daniel W. Van. The meaning of restorative justice. In: JOHNSTONE, Gerry; NESS, Daniel W. Van (eds.). Handbook of Restorative Justice. Cullompton: Willan Publishing, 2007, p. 5-23.

KERCHOVE, Michel van de. La justice restauratrice au cour du conflit des paradigmes de la peine. Histoire de la justice, Paris, n. 25, p. 123-133, 2015. https:// doi.org/10.3917/rhj.025.0123

LARRAURI, Elena. La herencia de la criminología crítica. $2^{\text {a }}$ ed. México: Siglo XXI Editores, 1992.

LLEWELLYN, Jennifer J.; HOWSE, Robert. Restorative Justice: A Conceptual Framework. Ottawa: Law Commission of Canada, 1999.

MACHADO, Pedro Sá. A mediação penal-restaurativa e o processo penal-consensual: uma discussão acerca da verdade a partir da Lei n ${ }^{\circ}$ 21/2007, de 12 de Junho. In: ANTUNES, Maria João; SANTOS, Cláudia Cruz; AMARAL, Cláudio do Prado (coords.). Os Novos Atores da Justiça Penal. Coimbra: Almedina, 2016, p. 163-191.

MARSHALL, Tony. The evolution of restorative justice in Britain. European Journal on Criminal Policy and Research, The Hague, Amsterdam, New York, v. 4, n. 4, p. 21-43, 1996. https://doi.org/10.1007/BF02736712

MATHIESEN, Thomas. The Politics of Abolition Revisited. Abingdon: Routledge, 2015.

MATHIESEN, Thomas. The Abolitionist Stance. Journal of Prisoners on Prisons, Ottawa, v. 17, n. 2, p. 58-63, 2008.

MATHIESEN, Thomas. Prison on Trial. 3rd ed. Winchester: Waterside Press, 2006.

MIERS, David. An International Review of Restorative Justice. Crime Reduction Research Series. London: Home Office, 2001.

MORÃO, Helena. Justiça restaurativa e crimes patrimoniais. In: PALMA, Maria Fernanda; DIAS, Augusto Silva; MENDES, Paulo de Sousa (orgs.). Direito Penal económico e financeiro: conferências do curso pós-graduado de aperfeiçoamento. Coimbra: Coimbra Editora, 2012, p. 257-279.

NESS, Daniel W. Van; STRONG, Karen Heetderks. Restoring justice: an introduction to restorative justice. $4^{\text {th }}$ ed. New Providence: LexisNexis, 2010.

NEW ZEALAND. Ministry of Justice. Restorative justice: best practice framework. Wellington: National Office, 2017. Disponível em: <https://www.justice.govt.nz/ assets/Documents/Publications/restorative-justice-best-practice-framework-2017. pdf>. Acesso em: 01 fev. 2019. 
OLIVEIRA, Ana Sofia Schmidt de; FONSECA, André Isola. Conversa com um abolicionista minimalista. Revista Brasileira de Ciências Criminais, São Paulo, A. 6, n. 21, p. 13-22, 1998.

ORGANIZAÇÃO DAS NAÇÕES UNIDAS. Conselho Econômico e Social. Resolução 2002/12, de 24 de julho de 2012. Disponível em: <http://www.un.org/en/ecosoc/ docs/2002/resolution\%202002-12.pdf>. Acesso em: 01 fev. 2019.

PALI, Brunilda. Justiça ativa: Processos de justiça restaurativa como campo fértil para o exercício da cidadania. Sistema Penal \& Violência, Porto Alegre, v. 6, n. 1, p. 31-42, 2014. https://doi.org/10.15448/2177-6784.2014.1.16721

PALLAMOLLA, Raffaella da Porciuncula. A mediação penal no Brasil: presente e futuro. In: MELLO, Kátia Sento Sé; BAPTISTA, Bárbara Gomes Lupetti; FILPO, Klever Paulo Leal (orgs.). Potencialidades e incertezas de formas não violentas de administração de conflitos no Brasil e na Argentina. Porto Alegre: Evangraf, 2018, p. 137-159.

PALLAMOLLA, Raffaella da Porciuncula. Justiça restaurativa: da teoria à prática. São Paulo: IBCCRIM, 2009.

PARKER, Lynette. Circles. Centre for Justice \& Reconciliation. Disponível em: <http://restorativejustice.org/restorative-justice/about-restorative-justice/tutorial -intro-to-restorative-justice/lesson-3-programs/circles/>. Acesso em: 30 jan. 2019.

PAVARINI, Massimo. Strategy for combat: prisoners' rights and abolitionism. Justice, Power and Resistance, London, v. 1, n. 1, p. 67-79, 2017.

PORTUGAL. Assembleia da República. Proposta de Lei n. ${ }^{\circ}$ 107/X: Relatório, conclusões e parecer da Comissão de Assuntos Constitucionais, Direitos, Liberdades e Garantias. Disponível em: <http://debates.parlamento.pt/catalogo/r3/dar/ s2a/10/02/047/2007-02-23/30?pgs=30-35\&org=PLC>. Acesso em: 28 jan. 2019.

PORTUGAL. Direção-Geral da Política de Justiça. Sistema de Informação das Estatísticas da Justiça. Estatísticas Oficiais da Justiça. Disponível em: <http://www. siej.dgpj.mj.pt>. Acesso em: 02 fev. 2019.

RAYE, Barbara E.; ROBERTS, Ann Warner. Restorative processes. In: JOHNSTONE, Gerry; NESS, Daniel W. Van (eds.). Handbook of Restorative Justice. Cullompton: Willan Publishing, 2007, p. 211-227.

ROBALO, Teresa L. Albuquerque e Sousa. Dois modelos de justiça restaurativa: a mediação penal (adultos) e os family group conferences (menores e jovens adultos). Revista Portuguesa de Ciência Criminal, Coimbra, A. 22, n. 1, p. 79-128, 2012.

ROSENBLATT, Fernanda Fonseca. Lançando um olhar empírico sobre a justiça restaurativa: alguns desafios a partir da experiência inglesa. Revista 
Brasileira de Sociologia do Direito, Porto Alegre, v. 1, n. 2, p. 72-82, 2014. https:// doi.org/10.21910/rbsd.v1n2.2014.28

RUGGIERO, Vicenzo. The Legacy of Abolitionism. Champ Pénal/Penal Field, Paris, v. XXI, 2015. https://dx.doi.org/10.4000/champpenal.9080.

RUGGIERO, Vincenzo. An abolitionist view of restorative justice. International Journal of Law, Crime and Justice, Amsterdam, v. 39, n. 2, p. 100-110, 2011, pp. 100-101. http://dx.doi.org/10.1016/j.ijlcj.2011.03.001.

RUGGIERO, Vicenzo. Penal Abolitionism: a celebration. Oxford: Oxford University Press, 2010.

RUIVO, Marcelo Almeida. O fundamento da pena criminal: para além da classificação dicotômica das finalidades. Revista Portuguesa de Ciência Criminal, Coimbra, A. 22, n. 2, p. 175-199, 2012.

SANTANA, Selma Pereira de; SANTOS, Carlos Alberto Miranda. A justiça restaurativa como política pública alternativa ao encarceramento em massa. Revista Brasileira de Políticas Públicas, Brasília, v. 8, n. 1, p. 227-242, 2018. https://doi. org/10.5102/rbpp.v8i1.5059

SANTOS, Cláudia Cruz. A justiça restaurativa: um modelo de reacção ao crime diferente da justiça penal: porquê, para quê e como?. Coimbra: Coimbra Editora, 2014.

SANTOS, Cláudia. Um crime, dois conflitos (e a questão, revisitada, do 'roubo do conflito’ pelo Estado). Revista Portuguesa de Ciência Criminal, Coimbra, A. 17, n. 3, p. 459-474, 2007.

SAWIN, Jennifer Larson; ZEHR, Howard. The ideas of engagement and empowerment. In: JOHNSTONE, Gerry; NESS, Daniel W. Van (eds.). Handbook of Restorative Justice. Cullompton: Willan Publishing, 2007, p. 41-58.

SCHEERER, Sebastian. Hacia el Abolicionismo. In: CIAFARDINI, Mariano Alberto; BONDANZA, Mirta Lilián (orgs.). Abolicionismo Penal. Buenos Aires: Ediar Sociedad Anonima Editora, Comercial, Industrial y Financiera, 1989, p. 15-34.

SHAPLAND, Joanna; CRAWFORD, Adam; GRAY, Emily; BURN, Daniel. Learning lessons from Belgium and Northern Ireland. Sheffield: University of Sheffield, 2017.

SHECAIRA, Sérgio Salomão. Criminologia. $5^{\mathrm{a}}$ ed. rev. São Paulo: Editora Revista dos Tribunais, 2013.

SULLIVAN, Dennis; TIFFT, Larry (Ed.). Handbook of Restorative Justice: A Global Perspective. London, New York: Routledge, 2006.

TIEGHI, Osvaldo Nelo. El abolicionismo radical y el abolicionismo institucional. Revista Chilena de Derecho, Santiago, v. 22, n. 2, p. 309-319, 1995. 
UNIÃO EUROPEIA. Parlamento Europeu e Conselho da União Europeia. Diretiva 2012/29/UE do Parlamento Europeu e do Conselho, de 25 de outubro de 2012. Disponível em: <https://eur-lex.europa.eu/legal-content/PT/TXT/HTML/?uri=CELEX:32012L0029>. Acesso em: 01 fev. 2019.

UNITED NATIONS. Office on Drugs and Crime. Handbook on Restorative Justice Programmes. New York: United Nations, 2006.

WALGRAVE, Lode. La justice restaurative: à la recherche d'une théorie et d'un programme. Criminologie, Montréal, v. 32, n. 1, p. 7-29, 1999. https://doi. org/10.7202/004751ar.

ZAFFARONI, Eugenio Raúl. Em busca das penas perdidas: a perda da legitimidade do sistema penal. Tradução: Vania Romano Pedrosa, Amir Lopes da Conceição. Rio de Janeiro: Revan, 1991.

ZEHR, Howard. The Little Book of Restorative Justice. Versão eletrônica. New York: Good Books, 2014.

ZEHR, Howard. Changing lenses: a new focus for crime and justice. Scottdale: Herald Press, 1990.

\section{Informações adicionais e declarações dos autores (integridade científica)}

Declaração de conflito de interesses (conflict of interest declaration): o autor confirma que não há conflitos de interesse na realização das pesquisas expostas e na redação deste artigo.

Declaração de autoria e especificação das contribuições (declaration of authorship): todas e somente as pessoas que atendem os requisitos de autoria deste artigo estão listadas como autores.

Declaração de ineditismo e originalidade (declaration of originality): o autor assegura que o texto aqui publicado não foi divulgado anteriormente em outro meio e que futura republicação somente se realizará com a indicação expressa da referência desta publicação original; também atesta que não há plágio de terceiros ou autoplágio. 
Dados do processo editorial

(http://www.ibraspp.com.br/revista/index.php/RBDPP/about/editorialPolicies)

- Recebido em: 10/12/2018 Equipe editorial envolvida

- Controle preliminar e verificação de plágio:

- Editor-chefe: 1 (VGV) 15/12/2018

- Avaliação 1: 21/12/2018

- Editor-associado: 1 (ELL)

- Avaliação 2: 28/12/2018

- Revisores: 4

- Avaliação 3: 08/01/2019

- Avaliação 4: 11/01/2019

- Decisão editorial preliminar: 20/01/2019

- Retorno rodada de correções: 10/02/2019

- Decisão editorial final: 15/02/2019

\section{COMO CITAR ESTE ARTIGO:}

RIBOLI, Eduardo Bolsoni. Um "tribunal orientado para a vítima": o minimalismo de Nils Christie e as suas contribuições à justiça restaurativa. Revista Brasileira de Direito Processual Penal, Porto Alegre, vol. 5, n. 1, p. 253-298, jan./abr. 2019. https://doi.org/10.22197/rbdpp.v5i1.203

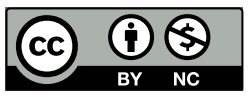

Esta obra está licenciada com uma Licença Creative Commons Atribuição-NãoComercial 4.0 Internacional. 